\title{
The fifteenth-century Catalan translation of the French Danse macabre: \\ A critical edition and English translation, from manuscript Miscel-lània 26, Arxiu de la Corona d’Aragó, Barcelona
}

\author{
Alina Zvonareva \\ Università degli Studi di Padova \\ alina.zvonareva@gmail.com \\ http://orcid.org/OOOO-OOO3-3587-2856 \\ Rebut 23/O7/2OI4; acceptat 20/II/2OI4 \\ DOI Io.7203/MCLM.2.3902
}

\begin{abstract}
The present article focuses on ff. CXLr-CLIVr of manuscript Miscel-lània 26, Arxiu de la Corona d'Aragó, Barcelona, which contain the only extant version of the fifteenth-century Catalan translation of the French Danse macabre. The article contains a philological study of this section of the manuscript, with particular attention to the relationship between the Catalan version of the Danse macabre and its French sources: this study serves as an introduction to a new critical edition of the Catalan translation proposed in the second part of the article. The critical text consists of a parallel edition of the Catalan version and manuscript lat. I4904, Bibliothèque nationale de France, Paris (MS BnF lat. I49O4), which proves to be the witness of the French poem closest to the lost exemplar used by the Catalan translator. Both editions aim at finding a balance between readability and a conservative approach which preserves the historical character of the manuscripts. The critical text is preceded by editorial criteria and accompanied by a literal translation into modern English and editorial notes.
\end{abstract}

\section{KeYwords}

Dance of Death; Danse macabre; Dansa de la Mort, Dança de la Mort; critical edition; Catalan literature; textual transmission and reception; medieval translation; manuscript tradition; Pere Miquel Carbonell; manuscript Miscel-lània 26, Arxiu de la Corona d'Aragó; manuscript lat. I4904, Bibliothèque Nationale de France; Abbey of Saint Victor in Paris; John Lydgate.

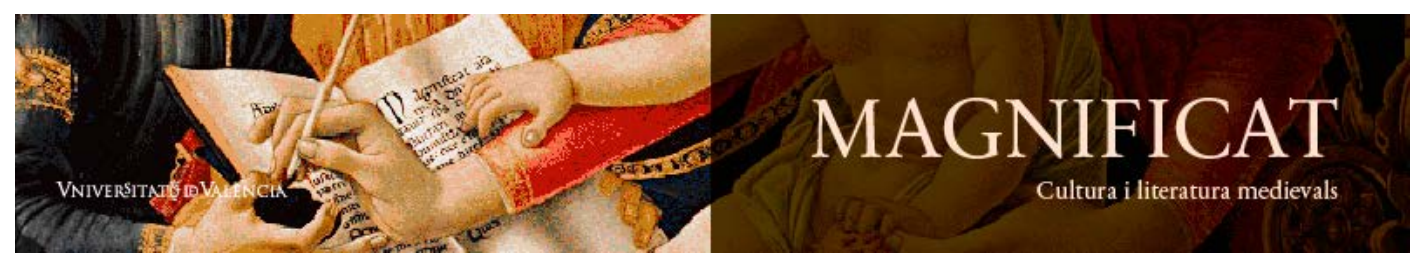

Magnificat Cultura i Literatura Medievals 2, 20I5, I-53. http://ojs.uv.es/index.php/MCLM

ISSN $2386-8295$ 
La traducció catalana quatrecentista de la "Danse macabre" francesa: edició crítica del ms. Miscel-lània 26, Arxiu de la Corona d’Aragó, i traducció a l’anglès RESUM

El present article se centra en els ff. cxur-CLIvr del manuscrit Miscel-lània 26, Arxiu de la Corona d’Aragó, Barcelona, que contenen l'única versió conservada de la traducció catalana de la Danse macabre francesa. L'article inclou un estudi filològic d'aquesta secció del manuscrit, amb atenció particular a la relació entre la versió catalana de la Danse macabre i les seues fonts franceses : aquest estudi serveix d'introducció a una nova edició crítica de la traducció catalana, proposada en la segona part de l'article. El text editat presenta edició en paral-lel de la versió catalana i del manuscrit lat. I49O4, Bibliothèque Nationale de France, Paris (MS BnF lat. I49O4), que resulta ser el testimoni del poema francès més proper a l'exemplar perdut emprat pel traductor català. En ambdues edicions se cerca un equilibri entre fâcil lectura i transcripció filològica per conservar el caràcter històric dels manuscrits. L’edició crítica és precedida pels criteris editorials, i seguida d'una traducció a l'anglès actual, i per notes d'edició.

PARAULES CLAU

Dansa de la Mort; danses macabres; Danse macabre; edició crítica; literatura catalana; transmissió i recepció textuals; traducció medieval; tradició manuscrita; Pere Miquel Carbonell; manuscrit Miscel-lània 26, Arxiu de la Corona d'Aragó; manuscrit lat. I4904, Bibliothèque Nationale de France; abadia de Sant Víctor a París; John Lydgate.

Alina Zvonareva, 20I5, "The fifteenth-century Catalan translation of the French Danse macabre: a critical edition and English translation, from manuscript Miscel-lània 26, Arxiu de la Corona d'Aragó, Barcelona”, Magnificat Cultura i Literatura Medievals 2, I-53.

\section{TABLE OF CONTENTS}

Introduction -3

I.I "Danse macabre" and its transmission - 3

2 The Catalan translation: philological study -5

2.I The extant manuscript of the Dança de la Mort: the original or a copy? - 5

2.2 In search of the lost source: the relationship between the Parisian "Danse macabre" and its Catalan translation - 6

2.3 Translation patterns -9

3 The Dança de la Mort from MS Miscel-lània 26, Arxiu de la Corona d'Aragó, and Danse macabre from MS BnF lat. I4904: parallel critical edition - I2

3.I Editorial criteria - I2

3.I.I Syntax: general criteria - I2

3.I.I.I Catalan text - I2

3.I.I.2 French text - I2

3.I.2 Diacritics - I3

3.I.2.I Catalan text - I3

3.I.2.2 French text - I3

3.I.3 Spelling: general criteria - I3

3.I.3.I Catalan text - I3

3.I.3.2 French text - I4

3.I.4 Grammar: French text - I4

3.I. 5 Editorial interventions - I4

3.I.6 Apparatus - I4

3.I.7 Numeration - I4

3.2 Critical text - I5

$3 \cdot 3$ Editorial notes -29

3.3.I Catalan text -29

3.3.2 French text -34

${ }_{4}$ Conclusions and results -35

5 English translation - 35

6 Acknowledgements - 49

7 Works Cited - $5^{\mathrm{O}}$ 


\section{$\Rightarrow * \approx$}

\section{Introduction}

$\mathrm{T}_{\mathrm{h}}$ his article aims at providing a new critical edition of the only extant manuscript version of the Dança de la Mort, a fifteenth-century Catalan translation of the famous Danse macabre of the Cemetery of the Innocents in Paris. The manuscript in question is Barcelona, Arxiu de la Corona d'Aragó, MS Miscel-lània 26 (henceforth B), ff. CXLr-CLIVr. ' The lack of a modern edition of the Dança de la Mort means that this text is often neglected by scholars studying the early Dance of Death tradition. The only existing editions of this text are in Bofarull I864-65, 267-96 and Aguiló i Fuster I90o (pages unnumbered): both are outdated and scarcely reliable; moreover, the latter is a popularising edition.

\section{I.I "Danse macabre" and its transmission}

The artistic genre of the Dance of Death (or Dance of the Dead) ${ }^{2}$ developed and spread in Europe in the late fourteenth-fifteenth century. ${ }^{3}$ This peculiar phenomenon of late medieval culture is normally expressed by series of dialogues between a personified Death - or a dead person - and representatives of different social classes placed in descending hierarchical order - from the pope and the emperor to the most marginal social figures, religious and lay people alternating. ${ }^{4}$ This genre takes different forms, such as a mural painting with or without accompanying text, a dialogue poem, a manuscript miniature or a series of miniatures, a dramatic action, wood or stone sculptures, or an authentic ritual dance. ${ }^{5}$ This formal plurality is balanced by a number of common characteristics at the level of content: most examples of the Danse macabre genre are distinguished

I. A second manuscript (Barcelona, Arxiu de la Corona d'Aragó, MS Memorial 49) once included the Dança de la Mort, but the relevant leaves have been lost: see Massip-Morrás 20I4, 448 fn. 4.

2. As far as the name of the whole genre is concerned, the English expression Dance of Death and the French expression Danse macabre are normally used as almost full synonyms in scholarly works on the subject; this article follows the established tradition.

3. Among the studies published recently on the Danse macabre, it is worth citing Massip-Kovács 2004a; Oosterwijk 2004; Gertsman 20IO; Oosterwijk-Knöll ed. 2OII.

4. The difference between Death and the Dead is probably much less important than it might seem; see Warda $20 I I a$. On the hierarchical order, see ibid., 8I-9O.

5. The diversity of the forms that this genre takes in its earliest attestations is described in Oosterwijk-Knöll ed. 2OII, 2-3 (editors' introduction). The Dance of Death is expressed most frequently through literature and painting. Víctor Infantes proposes distinguishing the 'complete' Dances combining both text and images, the 'graphic' ones containing images without textual elements, and the 'textual' ones containing text without pictorial elements (see Infantes I997, 2I-22). The relationship between text and image - if both elements are present - is extremely important as it helps to better understand the nature of the genre and the particularities of its evolution; see, e.g. Taylor ig89a. Furthermore, it can happen that the textual and the visual elements become separated: for instance, this is the case of the Danse macabre of the Cemetery of the Innocents in Paris, the source of the text studied in this article. See Oosterwijk 2008, I4O: "It is curious (...) that none of the extant early manuscript copies of the poem carry illustrations (...). Yet not long after the creation of the mural we find early books of hours containing Danse macabre scenes without any accompanying text as part of their decorative scheme. In other words, although text and image were combined to great effect in the mural at les Innocents, these two components were soon separated so that the poem was reproduced as a text without illustrations, while the images were apparently recognisable enough to function independently of the dialogue poem”.

For the role of dance rituals in the Dance of Death tradition, see Hammerstein r980; Massip-Kovács 2004a (especially $139-43, \mathrm{I} 46-63$ ).

$$
\text { Magnificat CLM 2,20I5, I-53. ISSN 2386-8295 }
$$


by an ironic and often satirical tone and the idea of reminding humans that they will inevitably die and turn to ashes, regardless of their social position and privileges they used to enjoy in their earthly life. In this regard, the relationship between the Dance of Death genre and the homiletic tradition, particularly that of the mendicant orders, is important. ${ }^{6}$

The Dance of Death is situated in a precise historical moment and at the same time in eternity; its appeal is concrete and at the same time universal. ${ }^{7}$ The choice of the linguistic code for these works - the vernacular languages in most cases - is meaningful. ${ }^{8}$ The need to make their message understandable and accessible to everyone gave rise to many translations of these texts. Consequently, the translator's activity played an important role in the transmission, reception and evolution of the Danse macabre. For the Germanic world, the Latin-German Totentanz or the Copenhagen Dance could be mentioned: the former is the oldest extant Dance of Death in Germany and it is considered a translation from Latin into German, while the latter is a translation of the Lübeck Dance from German into Danish. ${ }^{9}$ The Dance of Death that had definitely the widest circulation in Europe is the famous Parisian Danse macabre, painted in I424-I425 at the Cemetery of the Innocents and destroyed in the seventeenth century (but surviving in numerous handwritten and printed copies); this work arrived in England through a translation by John Lydgate (probably

6. Alan Hindley insists on “la parenté entre les danses macabré et l'art théâtral, entre les méthodes du prédicateur et du dramaturge" (Hindley 2007, I88). On the relationships of the Dance of Death to the preaching tradition and to the medieval theatre, see also Taylor $1989 \mathrm{~b}$; Taylor I99O, and, for the Catalan-speaking context, Massip-Kovács 2004a, 556I, II5-23; Massip-Kovács 2004b, 9I-IO5; Massip 2007, 257-59.

7. "The strength of the Danse - and probably the reason for its endurance - is no doubt its adaptability: it was capable of incorporating or emphasising different metaphors from dance and music to violence, pious thought and social satire, stereotypes and individual portraits. (...) The Danse could be expanded or reduced, altered and updated” (Oosterwijk 2OII, 4I). Derek Pearsall defines the Dance of Death as "a kind of do-it-yourself kit which anyone could add to", pointing out that "there are many opportunities for enthusiastic copyists to introduce new stanzas in such a poem" (Pearsall i987, 62-63).

Such addition of new characters by later copyists or editors occurs, for instance, in the I 486 edition by Guy Marchant (v. infra fn. Io) and in some manuscripts transmitting Lydgate's English translation of the French Danse (v. ibidem). Another interesting example of this tendency is the sequel of the Catalan text studied in this article. This sequel of the Dança de la Mort, written by Pere Miquel Carbonell and Gaspar Nadal, is transmitted in the same manuscript as the poem that served as a model for it: Barcelona, Arxiu de la Corona d’Aragó, MS Miscel lània 26, ff. CLIVr-CLXIIIv. Both texts were handwritten by the same person, the royal archivist Carbonell, but, whereas in the case of the Dança de la Mort we are faced with a copy ( $v$. infra 2.I), in that of its sequel we have an original autograph version. Like Marchant or the copyists of Lydgate's poem, Carbonell does not limit himself to copying the Dance of Death, but adds a number of new stanzas to his source. An important particularity that distinguishes this sequel is that Carbonell clearly separates his source text, composed by someone else, from the reworking he himself makes of it - therefore, the poems become two; in contrast, in Marchant's I 486 edition and the reworkings of Lydgate's translation, the source text simply becomes enriched with new elements, therefore the poem remains one. Carbonell does not alter the structure of the text he copies, but adds a second Dance of Death after the first one, thus conceiving it as an autonomous poem and demarcating his own new text from its prototype. Another feature that makes Carbonell's sequel interesting in the context of the whole Dance of Death tradition lies in the fact that the group portrait painted by Carbonell is not universal (the entire society, as it is in the majority of the examples of the Danse macabre genre), but restricted and concrete (the royal court in Barcelona): the poem represents the hierarchy of different employees placed in the administration of the Crown of Aragon, and it contains allusions to people still alive, although the author gives no name. For an analysis of Carbonell's Dance of Death, see Massip-Morrás 2OI4. For the hypothesis of the representation of real historical figures in many textual and visual Dances of Death, see Oosterwijk 2008 and Oosterwijk 20 ог.

8. See Freytag 2OII, xxi.

9. The Latin-German Totentanz is transmitted in a manuscript dated I443-I447 (Heidelberg, Universitätsbibliothek, MS Cpg 3I4, ff. lxxixr- lxxxv); the Danish dance appeared for the first time in a printed edition published in I55O by Hans Vingaard. On these two texts, see Warda 2OIIb, 2O4-2IO and I32-I4O respectively (with other bibliographical references). 
made in I426), which was used as an accompanying text for murals in the cloisters of St. Paul's Cathedral in London. ${ }^{\text {IO }}$ Lydgate's poem inspired many literary and pictorial representations of the Dance of Death in the English tradition. ${ }^{\text {II }}$

Similarly, the Catalan-speaking world was influenced by the French model. ${ }^{12}$ Although the Iberian Peninsula produced one of the most ancient Dances of Death, specifically the Castilian Dança General de la Muerte, dating from I39O-I400, our Dança de la Mort is independent of the Spanish text, being derived directly from the French source. This places the Catalan translation from manuscript $\mathbf{B}$ in the broad tradition of transmission and consumption of French texts in the fourteenth and fifteenth-century Crown of Aragon. ${ }^{33}$

\section{The Catalan translation: philological study}

\section{I The extant manuscript of the Dança de la Mort: the original or a copy?}

Manuscript B was written in the late fifteenth century by the humanist Pere Miquel Carbonell, royal archivist of the Crown of Aragon. There are two opposite opinions on the authorship of the Catalan translation contained in this manuscript: many scholars attribute it to Carbonell himself, whereas others opine that the archivist merely copied the Catalan text of the Danse macabre. ${ }^{\mathrm{I} 4}$ This latter hypothesis is definitely more convincing: in fact, it is more likely that the Catalan translation is anonymous and chronologically not too distant from the original French poem.

Alfred Morel-Fatio and Florence Whyte stress the importance of the impersonal construction és stada traduida 'was translated', used by Carbonell to describe the Catalan Dance of Death in a note placed after the text: in their opinion, this note indicates that Carbonell's version is only a copy, whereas the original must be older (Morel-Fatio I872, 254 and Whyte I931, 27).

A more important proof of the priority of the Dança de la Mort to the version transmitted by $\mathbf{B}$ is the presence of some undoubted copying errors found in this manuscript: l'a[lt]re 20.8, vostra $\langle s\rangle$ grimaça 37.3, monstrar instead of monstrau 50.8 , gordattat instead of gordanat $5^{2.7}$, mo y falli $<t>$

IO. The Parisian Danse macabre lacks a critical edition. Most studies examining or simply mentioning this text refer to a late fifteenth-century printed edition, namely the version with engravings printed in $\mathrm{I}_{4} 85$ by Guy (or Guyot) Marchant and reissued with some modifications in I486; a modern facsimile of the I 485 version can be found in Kaiser I983, 74-IO7 and Fein 2OI3, 22-53. However, we should be aware that Marchant's editions bring many innovations to the (hypothetical) original text.

For the critical edition of Lydgate's poem, see Warren ed. I93I. For an analysis of this text, see Oosterwijk 20 oro.

II. See Oosterwijk 2009.

I2. In this article, the Catalan text will be often compared to Lydgate's version, as it results in a better understanding of the peculiarities of the Catalan translation.

I3. For the influence French poetry exercised upon Catalan texts in the fourteenth and especially in the fifteenth century, see Marfany 2OIO; Marfany 2012 and other works by this author. For a more general framework for the late medieval transmission and reception of the European literary tradition in the Catalan-speaking world, see Alberni $e t a l$. ed. 2OIO.

I4. The hypothesis stating that the translation was made by Carbonell himself was postulated for the first time by the first editor of the Dança de la Mort (Bofarull I864-65, 260), and it is still considered valid in some modern studies, e.g. Infantes 1997, 82; Corvisier 1998, 82; Merlo 2000, 226. Nevertheless, the idea that Carbonell is not to be seen as a translator but as a simple copyist was expressed already in I872: see Morel-Fatio I872, 254. This opinion was adopted by a number of later researchers: see Whyte I93I, 27; Kurtz I975 (1934), I49; Romeu i Figueras 1957-58, 203; Massot i Muntaner 1983, 347; Massip-Kovács 2004a, 69. 
59.6, and probably also pus $\mathrm{I} 9.2$ (see the respective editorial notes). ${ }^{5}$ These errors should not necessarily be attributed to Carbonell - or, at least, not all of them, as it is plausible that there were other intermediate copies - but such errors lead us to reject the idea that the extant version is the original one. This means that, aside from the extant manuscript studied here, there were other copies of the Catalan translation, which made possible the circulation of the text in the lands of the Crown of Aragon. ${ }^{16}$

\subsection{In search of the lost source: the relationship between the Parisian "Danse macabre" and its Catalan translation}

\section{The Dança de la Mort e de aquelles persones qui mal llur grat ab aquella ballen e dançen, copied} by Carbonell, is a translation that aspires to faithfulness: for instance, the translator preserves the octosyllabic metre and the strophic structure, specifically the pattern ABABBCBC. The order of appearance of the characters in the Catalan text also shows a very close adherence to the French source, as evidenced by the following list (limited to the first ten victims in the two texts): le Pape = el Papa (the Pope); l'Empereur = l'Emperador (the Emperor); le Cardinal = el Cardenal (the Cardinal); le Roi = el Rey (the King); le Patriarche = el Patriarcha (the Patriarch); le Connétable = el Capità o Conestable (the Captain or Constable); l'Archevéque = l'Archabisbe (the Archbishop); le Chevalier = el Cavaller (the Knight); l'Évéque = el Bisbe (the Bishop); l'Écurier = le Gentilhome (the Squire); l'Abbé = l'Abbat (the Abbot); le Bailli = el Governador (the Bailiff). In both versions the duke is absent and the kings are two: the second is a dead body speaking from the grave. ${ }^{17}$ As far as the French poem is concerned, this order of characters brings us to the versions older than the second printed edition by Guyot Marchant (I486), which adds some more victims: Le Légat (the Papal Envoy), le Duc (the Duke), Le Maître d'École (the School Teacher), etc.; the absence of all these new characters in the Catalan translation leads us to reject the idea of the derivation of the Catalan text from Marchant's printed version of $\mathrm{I} 486 .^{18}$

I5. Here and below, the Catalan translation entitled the Dança de la Mort is quoted from the edition of B, ff. CXLrCLIVr, published in the second part of this article. All references to the critical edition contain a stanza number and a line number (or numbers, if a quotation includes more than one line), separated by a point.

I6. It is worth noting that we have evidence of the circulation of the Dança de la Mort in the ecclesiastical circles of the Balearic Islands: our Catalan translation of the Danse macabre is one of the sources for the Mallorcan play Representatió de la Mort. We cannot certainly affirm that this text arrived in Mallorca through other channels than Carbonell's version, but it is not impossible.

The edition of the Mallorcan play is in Romeu i Figueras $1957^{-58}$, subsequently republished in Romeu i Figueras 1995, I7-95. On the relationships between the Dança de la Mort and the Mallorcan Representatió de la Mort, see Zvonareva 2OI3, 297-3O2. On the authorship of the Mallorcan play, see Kovács 2OII, 2I4-I6.

I7. The absence of the duke and the presence of two kings probably had a historical explanation in the original text, since it is possible that the French people could recognise some real-world royal figures, most probably king Charles VI: see Oosterwijk 2008. Naturally, for a Catalan reader it would have been more difficult to catch such political allusions, and in any case their importance would have been lost.

I8. The extant manuscripts of the Parisian Danse macabre are MS lat. I4904, Bibliothèque Nationale de France, Paris (henceforth BnF); MS BnF fr. 25550; MS BnF fr. 25434; MS BnF fr. I4989; MS BnF fr. Io55; MS BnF fr. II8I; MS BnF fr. ıı86; MS BnF fr. 995; MS BnF, nouvelles acquisitions françaises (henceforth NAF) IOO32; MS Add 38858, British Library, London (henceforth Brit. Lib. Add 38858); MS I39 (364), Bibliothèque municipale, Lille (henceforth Lille I39); MS 9O7, Bibliothèque municipale, Tours (henceforth Tours 907); MS I27, Bibliothèque municipale, SaintOmer (henceforth Saint-Omer I27); MS 502, Musée Condé (Bibliothèque et les archives du château), Chantilly (henceforth Chantilly 502). MS BnF fr. 995 is a codex descriptus deriving from Marchant's I485 edition; MS Chantilly $5 \mathrm{O} 2$ is a codex descriptus deriving from Marchant's I 486 edition; the remaining manuscripts are independent of the printed versions. 
Another textual element compatible with this hypothesis is the lection honor, gaudia 'honour, joys' found in B, f. I53v, and in all the French manuscripts that do not derive from Marchant's editions and contain these Latin passages (it is very likely that the Parisian mural contained them as well), i.e. MSS BnF lat. I4904, BnF fr. 25434 , BnF fr. I 4989, BnF fr. I055, BnF NAF Ioo32, Lille I39. This is meaningful because in Marchant's editions of I 485 and I486 we read honor, gloria 'honour, glory': this divergence between the manuscripts and the printed versions makes it unlikely that the Catalan translation derived from either of Marchant's editions.

Some other remarks on the relationship between the Catalan translation and the transmission of the French Danse macabre can be made. Some structural and textual elements allow us to assume a relationship between the manuscript copied by Carbonell and one of the oldest manuscripts containing the Parisian Dance, specifically MS Paris, BnF lat. I49O4 (henceforth P). A significant piece of evidence consists in a reference note found in $\mathbf{B}$ and attributing the French source text to a misterious Johannes Climacus sive Climages (f. CLIIIV): as already pointed out by Whyte (I93I, 33-5) and Leonard Kurtz (I975 [I934], I5O), it is a cross between the names of Jean Gerson and Nicholas de Clamanges - two members of the Victorine circle whose works precede and follow the Danse macabre exactly in $\mathbf{P}$, a copy with provenance from the school of Saint Victor. ${ }^{19}$ It is therefore possible to establish a connection between the Catalan Dança de la Mort and the Abbey of Saint Victor in Paris.

Another, more important element that makes the Catalan translation closer to the Victorine branch of the Danse macabre tradition than to other witnesses of the French text is the denomination lo Mestre ('the Master, the Teacher') in the rubrics preceding the introductory and concluding lines of the poem. This word choice is interesting, as it does not match the most common variant in the manuscript and printed tradition l'acteur 'the Authority' nor most other variants used in the French manuscripts and in the I485 and I486 Marchant's editions, namely le docteur / doctor 'the Teacher, the Mentor', Macabre (used as a proper noun) or Angelus 'an Angel', used in the other French manuscripts and in the I485 and I486 Marchant's editions. ${ }^{20}$ Instead, the Catalan Mestre finds an equivalent in both extant Victorine manuscripts (P and BnF fr. 25550), where there is no mention of acteur, but of ung maistre qui est au bout de la dance 'A Master speaking at the beginning of this dance' (P 66 title; ${ }^{21} \mathrm{BnF}$ fr. 2555O, f. CCXLVIIV).

Another element to be analysed in the light of the stemmatic aspect is the choice of the feminine article $l a$ before the word mort in the manuscript rubrics that regularly precede the stanzas. ${ }^{22}$ Some manuscripts and printed versions of the Danse macabre use the masculine article le, thus interpreting the word as 'Dead', while others use the feminine article $l a$, thus referring to 'Death'. The constant use of the feminine article in the Catalan text cannot be considered as sufficient proof of its dependence upon one specific witness of the French poem. Nevertheless, this characteristic makes it more likely that the Dança de la Mort derives from a version containing the feminine

19. See Calvot-Ouy 1990, 88-94; Ouy 1999, 327-328.

20. Acteur is the reading of MSS BnF fr. $25434, \mathrm{BnF}$ fr. $\mathrm{II} 86$ and of both Marchant's editions; docteur is found in MSS Brit. Lib. Add $3885^{8}$ and BnF NAF IOO32; doctor is in MSS BnF fr. I4989 and BnF fr. IO55; Mac $<r>a b r e$ is in MS Saint-Omer I29; Machabre le docteur and Angelus are compresent in MSS BnF fr. I4989 and BnF NAF IOO32.

2I. Here and below, all quotations from $\mathbf{P}$ refer to the critical edition of this manuscript, ff. LXIVr-LXXIIr, provided in the second part of this article. All references to the edition contain a stanza number and a line number (or numbers, if a quotation includes more than one line), separated by a point. When quoting a rubric, the word title is used instead of line numbers.

22. Both in French and in Catalan the form mort corresponds to two morphological homonyms: it can stand for 'death' or for 'dead', feminine in the first case and masculine in the second. As for the form la of the feminine singular definite article, it is the same in French and Catalan. 
article before mort rather than from one containing only the masculine article. Among the latter are Marchant's editions and, interestingly, MS BnF fr. 2555 o, i.e. the second of the two extant manuscripts of the Danse macabre with provenance from the Abbey of Saint Victor. ${ }^{23}$ As for $\mathbf{P}$, it oscillates between the two grammatical genders without any logical reason: this evident oversight shows that the choice between the two forms had less importance for the fifteenth-century readers of the Danse macabre than for many contemporary scholars (also v.supra fn. 4 ) ${ }^{24}$ However, the presence of both articles in $\mathbf{P}$ is compatible with the above hypothesis of the relationship between this manuscript and the Catalan text. It is plausible that the Catalan translator had access to one of the manuscripts - now almost certainly lost - belonging to the same branch of the Victorine manuscript family as $\mathbf{P}$ and other than $\mathrm{BnF}$ fr. $2555 \mathrm{O}$. This lost source might have been constant in the choice of la mort (and faithfully followed by the Catalan version), but it is also possible that it fluctuated between la mort and le mort, which would mean that the Catalan translator regularised the use of these two forms, opting for la mort. Also, the choice of the feminine article is reflected in the title of the Catalan poem, where the adjective macabre, common in the French tradition, is replaced by the syntagma de la mort. It is possible that this innovation is to be attributed to the Catalan translator himself rather than to some French copyist in the chain of transmission: there is no attestation of the term macabre / macabra in the Catalan text, which suggests that the translator deliberately avoided it, probably perceiving it as a markedly French word, unfamiliar and unnatural in the Catalan-speaking context. ${ }^{25}$

There is a remarkable discrepancy between the Catalan text and the extant versions of the Parisian Danse macabre: the Catalan Dança includes four female characters, namely the Maiden (la Donzella), The Nun (la Monge), the Widow (la Viuda) and the Married Woman (la Maridada), whereas the known witnesses of the French poem adhere to the all-male scheme. ${ }^{26}$ This difference could be plausibly interpreted as an innovation brought in by the Catalan translator or by a scribe who executed some intermediate copy - in French - placed between the original text and the Catalan version. However, another explanation is possible. Besides four female characters mentioned above, the Dança de la Mort also adds the Notary (el Notari): this element closely matches the structure of Lydgate's English translation of the Danse macabre - more precisely, the structure of the version found in one branch of the manuscript tradition of this poem - where we find the Abbess, the Noble Lady, the Woman in Love and the Juror. ${ }^{27}$ The characters are not exactly identical, and the women in Lydgate's poem are three whereas in the Catalan text they are four; nevertheless, the concomitance of these two groups of characters makes it possible to formulate at least a hypothesis of a common prototype containing three or four female characters and a notary

23. See Calvot-Ouy 1990, I82-I84; Ouy 1999, 4I7-4I8.

24. Sophie Oosterwijk (2OII, II) rightly claims that such irregular alternation of forms found in the manuscript and printed tradition of the Parisian Danse macabre might be explained by linguistic reasons, namely by the fact that the form $l e$ is attested as the feminine article in some Middle French dialects. However, this explanation hardly works in the case of the Victorine manuscripts in question nor in the case of Marchant's editions, since no other attestation of le before a feminine noun is found in any of them. What is more, the use of le mort in these manuscripts and incunabula is limited to the rubrics, whereas in the main text of the poem we always read la mort; the only exception, in all the versions, is the context clearly referring to a dead person and not to Death: le mort le viffait avancer 'the dead person makes the living one go forward' ( $\mathbf{P}_{2.4}$; MS BnF fr. 2555o, f. CCLIIIr, etc.).

25. The origin and etymology of the term macabre are uncertain, if widely discussed. See the brief summary in Fein 2013, 2-3.

26. As it is known, the French Danse macabre des femmes is a separate poem, postdating the Danse des hommes and deeply influenced by it. The earliest witness of the Des femmes text is dated I482. See Harrison I994, I-2.

27. The manuscript families of Lydgate's poem are discussed in Warren ed. I93I, xxiv-xxxi; see also Oosterwijk 2OIO, I9O-I92 and 20O-2OI. 
or a juror. Further, whereas Lydgate's work can be defined as a reworking of its source rather than a true translation, the Dança de la Mort is characterised by less individuality and less freedom in the treatment of the source text: this suggests that the stanzas of the five 'additional' characters probably derive from something already existing in some French version of the Danse. ${ }^{28}$

\subsection{Translation patterns}

In addition to the 'macroscopic' structural elements shared by the French and the Catalan texts, the Dança de la Mort shows great faithfulness to its model at the microtextual level. Whole stanzas translated almost literally are not infrequent. For example, this is the case of the words addressed by Death to the Pope: ${ }^{29}$

\section{Danse macabre 3.I-8}

Vous qui vives, certainement, quoyqu'il tarde, ainsi danceres.

Mais quant? Dieu le scet seulement advises comment vous feres.

Dam, pappe, vous commenceres, comme le plus digne seigneur; en ce point honnorés seres: aulx grans maistres est dieü l'onneur.

'You who live, certainly, sooner or later, you will dance this way. But when? Only God knows it watch carefully how you will do that. Lord Pope, you will begin, as the highest lord. This way will you be honoured: honour is due to those of high office'.

\section{Dança de la Mort 3.I-8}

Vós qui viviu al món present, prest o tart aquí dançareu. Mas quant? Sab-ho Déu solament preneu esment com ho fareu. Don Papa, vós començareu, axí com pus digne senyor; en tal forma honrat sereu: als grans Mestres pertany honor.

'You who live in the present world, sooner or later, you will dance here. But when? Only God knows it watch carefully how you will do that. Lord Pope, you will begin, as the highest lord; This way you will be honoured: honour is due to those of high office'.

However, the Catalan translator often sacrifices some shades of meaning and other details to metrical regularity. Thus, the monologue of a Dead King speaking from his grave is characterised by a number of lexical and syntactic manipulations, which reduce its closeness to the formal aspect of the French text, but exercise a minor influence on the content level:

28. The assumption that the Catalan and English translations derive from a common archetype had been already outlined by Whyte (I93I, 28). Regarding the origin of the female characters in these texts, it is remarkable that the miniatures of a book of hours influenced by the Danse macabre also contain one such character (see the comments in Oosterwijk 2008, I4I). It might also be useful to examine the female characters in the German Dances of Death.

29. Here and below, the Parisian Danse macabre is quoted from my edition of P. V. supra fn. 2I. 


\section{Danse macabre 65.I-8}

Vous qui en ceste pourtraiture vees danser estas divers, penses qu'est humaine nature: ce n'est fors viande à vers. Je le monstre, qui gis envers: si ay-je esté roy couronnés telz serez vous, bons et pervers: tous estas sont aux vers donnés.

'You who, in this painting, see men of different conditions dancing, think about what human nature is: it is no more than food for worms.

I, who lie here, demonstrate it, and I was once a crowned king so will you be, the good and the sinners: men of all conditions are given to the worms'.

\section{Dança de la Mort 75.I-8}

Vosaltres qui la present dança mirau, ab tota aquesta gent, advertiu, vejau ma semblança: yo fuy gran rey e molt potent; ara só dins lo moniment, hon tenc podrits tots mos costats no seran sabens ni grossers que no sien als vèrmens lansats.

'You who watch the present dance with all these people [who participate in it], pay attention, look at my appearance: I was once a great king and a very powerful one; now I am in the grave, where my body has all rotted neither the wise nor the uncouth will avoid being thrown to the worms'.

It should be noted that in other cases the translator repeatedly shows much more freedom in the treatment of source material. He mitigates some of the sarcasm characteristic of the French poem, e.g. alegrar les dones totes $5^{\mathrm{O}} \cdot 3$ 'to entertain all women' instead of faire esjoir sots et sottez $5^{\mathrm{O}} \cdot 3$ 'to entertain foolish men and women' (Death to the Minstrel). It can also happen that, on the contrary, the translator accentuates the irony of the Parisian Danse macabre, e.g. cuytau lo pas, no sembleu bou 33.6 'speed up your pace, do not look like an ox'30 instead of il convient que par cy passes 33.6 'you have to pass through here' (Death to the Merchant).

An interesting modification strategy consists in extending the metaphor of dance in the Catalan version: it can be found in several contexts where the French source does not make use of it. Thus, in the French Danse we read: Ha, maistre, par là passeres 39.I 'Ha, sir, you will pass through here' (Death to the Monk), whereas the Catalan version of this line is the following: En Monjo, ab mi dançareu 39.I 'Sir Monk, you will dance with me'; or we find: Veniu prop mi, ballem abdos 46.3 'Come close to me, [and] let us dance together', instead of Vous estes prins, la mort vous pique 46.3 'You are captured, [and] Death stabs you' (Death to the Lover)..3'

The last remarkable feature that makes the Catalan translation differ from its French model concerns the so-called proverbs. ${ }^{32}$ In the French Danse macabre, proverbial locutions are an independent structural element; their position is metrically fixed (they always occupy the final, eighth line of each stanza), and they have a very specific function: they provide a synthesis of

30. In the Catalan linguistic picture of the world oxen are characterised as very slow animals, as they pulled wagons with heavy goods.

3I. It is interesting that the English translation by John Lydgate also features this innovation; see Taylor I994, I85. On the culturally determined symbolic value of the choreographic element in the Danse macabre tradition, see EustaceKing 2OII, 43-7I.

32. The term proverb is used here for convenience; however, it can be applied to the Danse macabre only conventionally, as pointed out in Taylor $1989 \mathrm{~b}, 2 \mathrm{I} 6$ : “au sens strict, les locutions sentencieuses de la Danse macabre seraient plutôt des dictons, (...) distinguer dicton, proverbe, sentence et maxime est une opération délicate; nous choisissons donc, et sous toute réserve, d'employer le mot proverbe, désignation qui au Moyen Âge semble généralement recouvrir toute locution sentencieuse". 
the whole stanza, which contributes to effect "une transformation du ponctuel à l'universel, de l'anecdotique à l'axiomatique" (Taylor I989b, 2I9). The Dança de la Mort is characterised by a rather free treatment of the proverbs present in its French source: it frequently happens that, in the Catalan version, these proverbs lose their logical and syntactic autonomy and sometimes even their proverbial character. In the following paragraphs I will describe the different types of proverb transformation that can be individuated.

First, the 'proverb' can come to occupy two lines instead of one, e.g. per la mort, qu'és camí estret, I passar cové, cosa.s forçada I6.7-8 'one must inevitably pass through Death, which is a narrow path', instead of quant faire le fault, c'est contrainte 16.8 'when one must do that [i.e. die], he is bound' (the Archbishop); La carn e ossos deu podrir, / mas no sab hom hon, com ni quant 22.7-8 'Flesh and bones have to rot, but no one knows where, how and when', instead of tous fault morir, on ne scet quant 22.8 'everyone has to die, [and] no one knows when' (the Squire); per Adam, qui fonc lo primer, / moriu per manjar una poma 27.7-8 'you die because of Adam, who was the first [human], as a result of his eating an apple', instead of tous fault morir pour une pomme 27.8 'everyone has to die because of an apple' (Death to the Astrologer).

Second, the 'proverb' can occupy only one, the final line, but be linked to the previous line by means of a conjunction: carno sap hom per qui s'ajusta 29.8 'since no one knows for whom he amasses [wealth]', instead of on ne scet pour qui on amasse 29.8 'no one knows for whom he amasses [wealth]' (Death to the Bourgeois); car tot treball requer salari $5^{2.8}$ 'as any effort requires a reward', instead of à toute peine est deu salaire $5^{2.8}$ 'any effort requires a reward' (Death to the Parish Priest); que tal cobeja que ha prou 33.8 'as he who has enough desires to have more', instead of tel convoite qui a asses 'he who has enough desires to have more'.

Third, in some cases the proverbial locution of the French source is replaced by a significantly different proverb: qui mal no fa no sent torment 4I.8 'who does no ill feels no pain', instead of à tout perdre est cop perilleux 4I.8 'to lose everything is a dangerous blow' (Death to the Usurer). It is also possible that the original 'proverb' is replaced by a related but more generic one: a la mort no $y$ val resistença 45.8 'resistance is useless against Death', instead of contre la mort n'a medicine 45.8 'there is no medicine against Death' (the Physician).

Fourth, the 'proverb' can be transformed into a remark of a personal nature, thus losing its universality: may pensí ballar en tal dança 40.8 'I have never considered dancing such a dance', instead of chascuns n'est pas joyeux qui dance 40.8 'not everyone who dances is happy' (the Monk).

Lastly, one case of interchange of the 'proverbs' used in Death's stanza and the respective victim's stanza is attested: poc resta d'açò que foll pensa 6o.8 'very little remains of what a fool thinks', instead of Dieu punit tout quant bon lui semble 'God punishes everyone who seems appropriate to him' and, vice versa, porta-se.n Déu ço que li plau 6r.8 'God brings away with him what he finds appropriate', instead of moult remaint de ce que folpense 'much remains [unfulfilled] of what a fool thinks'.

Unlike the English translation of the Parisian Danse macabre, which contains Verba translatoris and a Conclusio added by the translator John Lydgate, the Catalan text - in the version that has come down to us - contains no explicit reflection on the process of translation. However, Lydgate's statement specifying that the translator's intention is to follow the matter and not the form could also be applied to the translation model adopted by the anonymous author of the Catalan Dança de la Mort, who analyses the original text and then restores it using elements of his native language: the result of this process is a text oscillating between literal translation and free imitation. ${ }^{33}$

33. Lydgate's statement is the following: owte of the frensshe I drowe hit of entent / Not worde be worde but folwyng the substaunce, lines 665-66 (Warren ed. 1931, 76). These words have a formulaic nature (a topos modestiae), 


\title{
3 The Dança de la Mort from MS Miscel-lània 26, Arxiu de la Corona d'Aragó, and Danse macabre from MS BnF lat. I4904: parallel critical edition
}

\author{
3.I Editorial criteria
}

3.I.I Syntax: general criteria

\section{I.I.I Catalan text}

I) The use of capital and lower-case letters generally follows modern Catalan usage.

Manuscript B frequently uses capital letters when Death calls a character by name (i.e., names his social rank) for the first time. This interesting feature is kept unmodified in the critical text, as it shows that the copyist distinctly perceived a meaningful structural particularity common to the Dança de la Mort and to its French source: Death always marks a shift from one victim to another by explicitly referring to their position in society (also $v$. infra editorial note I5.2). This becomes particularly interesting if we compare the Catalan version to the extant French copies: none of them uses capital letters when naming the characters. Such usage of capital letters is not perfectly regular, and the critical edition reproduces the oscillation present in the manuscript.

Sporadic capital letters not covered by the pattern above are not preserved in the edition, but registered in the editorial notes. For example, the critical text contains als grans mestres 3.8, whereas the respective note reports B Mestres (capital M).

2) Word separation follows modern Catalan usage.

3) The most universal punctuation marks - such as full stop, comma, exclamation and question marks etc. - are introduced according to modern Catalan usage.

4) A raised point (punt volat) between a vowel and a consonant is used to separate agglutinated words in the manuscript whenever the modern apostrophe cannot be used, e.g. qui.s vol 2.4, No.m puix 4.5 .

5) An apostrophe marks elision of articles, clitic pronouns before verbs and of the preposition de, e.g. A l'Emperador 5 title, l'esbaït 7.I, m'an enganat I2.I, s'esmena 57.8, d'una massa 2.8, d'or 5.4. An apostrophe is also used between a personal pronoun and the elided pronoun en, e.g. me.n vaig 5.7, ma.n clam 7I.7, se.n curen 77.I.

6) A hyphen is used between a verbal form and an enclytical personal pronoun, e.g. leves-me 4.4, acostau-vos $\mathrm{I} 5 \cdot 2$, sab-ho 3.2 .

$$
\text { 3.I.I.2 French text }
$$

I) The use of capital and lower-case letters follows modern French usage. No capital letters are used whenever Death mentions the character's social rank (v. supra 3.I.I.I), as they do not compare in $\mathbf{P}$.

2) Word separation follows modern French usage.

3) The most universal punctuation marks - such as full stop, comma, exclamation and question marks etc. - are introduced according to modern French usage.

4) A hyphen between verbal forms and pronouns is used according to modern French usage, e.g.

see Timofeeva 2006; at the same time, Lydgate “postulates an unsystematic but particular model for translation: an interpretative strategy which allows the translator to distinguish what is essential in his source text from what is contingent” (Taylor I994, I85). 
fault-il 4.I, est-ce 6.7, tires-vous I5.2.

\section{I.2 Diacritics}

\section{I.2.I Catalan text}

I) The use of accents follows modern Catalan usage.

Accents are used to distinguish the following pairs of monosyllabic words: $a$ 'to, for' (dative preposition) I.7 and passim - à 'has' 55.4, 58.6; deu 'must' 22.7 and passim - Déu 'God' 3.3 and passim; don 'lord' 3.5 - dón '(I) give' 66.7 / '(he) gives' 63.7; dos 'two' I5.5-dòs 'back, shoulders' 57.4; fas '(you) do' (second-person singular present indicative form) 30.3, 7I.5, - fàs ' (I) do' (firstperson singular present indicative form) I3.3; feu '(you) do' (present tense or imperative) 7.I, 5 o.6 - féu '(it) made' (preterite tense) 70.2; ma 'my' 8.7 and passim / 'me' (clitic object personal or reflexive pronoun) 30.I, 62.3, 7.I - mà 'hand' 43.5, 62.3, 74.6; mes 'but' 69.5-mès 'put, placed' (past participle) 48.6, 54.7, 63.6 - més 'more' 20.4 and passim; mon 'my' I3.I and passim - món 'world' 3.I and passim; pres 'took' 24.I, 7I.4 / 'taken' 38.6, 38.8 - prés 'after' 36.6; sé 'I know' I6.I and passim - se (third-person reflexive pronoun) 2.3 and passim; són '(they) are' I2.5, 57.3, 77.I son 'his, her' 22.I, 25.8; vós 'you' plural (tonic personal pronoun, subject or object) 3.I and passim - vos 'you' plural (clitic object personal or reflexive pronoun) 15.2 and passim. The tonic object personal pronoun nós ' we / us' I5.4 carries an accent mark, even though there is no attestation of the respective clitic pronoun nos.

2) The use of dieresis follows modern Catalan usage, e.g. esbaït 7.I, conduït $5^{8.7}$.

\section{I.2.2 French text}

I) Accents are normally introduced only in final position, for greater readability of the text, e.g. forgié 2.8. The use of these accents follows modern French usage.

Accents are also used to distinguish the following pairs of monosyllabic words: $a$ 'has' 9.8 and passim - $\dot{a}$ 'to, for' (dative preposition) I.6 and passim; ou 'or' 53.I, 55.3, 63.I / contraction of the preposition $\dot{a}$ with the masculine definite article le (variant of $a u$ ) 40.5-où 'where' I6.I and passim.

2) Dieresis (tréma) is not normally used. The only exception is the couple Dieu 'God' $3 \cdot 3$ and passim - dië̈ 'due' (past participle of devoir) 3.8, where the dieresis has a distinctive function.

\section{I.3 Spelling: general criteria}

\section{I.3.I Catalan text}

I) The use of the letters $u$ and $v$ is regularised according to modern usage.

2) The use of the letters $i$ and $j$ for the voiced palatal fricative is regularised according to modern usage. The only attestations of $j$ with this phonetic value are jurar 24.4 , Jove 46 .I, desijada 55.I, jorns 6I.I. In addition, the manuscript contains Jnfant $5^{8 . I}$ (corrected in the critical text), which confirms that there is no regularity in the choice of one of the two variants.

3) The non-etymological use of the letters $a$ and $e$ in atonic positions and the consequent oscillation between them are kept unchanged, as they are linguistically significant (for instance, $v$. infra editorial note I9.5).

4) The modern graphic unit l.l is used in rebel.lau 37.2 and rebel.lar 56.5. However, the overall tendency of $\mathbf{B}$ is to use the double $/$ f for the palatal $/ K /$ - e.g. aquelles title, mirall $2 . \mathrm{I}-$ and not for the velarised geminate $/ \mathrm{H} /$.

5) A prosthetic $e$ - is never integrated, e.g. no pusc scapar 38.7, mon studi 45.2. However, the 
cases when such $e$ - is likely to be really pronounced are discussed in the editorial notes.

$$
\text { 3.I.3.2 French text }
$$

I) The use of the letters $u$ and $v$ is regularised according to modern usage.

2) The use of the letters $i$ and $j$ for the voiced palatal fricative is regularised according to modern usage.

3) The use of the letters $z$ and $s$ is not regularised. The grapheme $z$ is usually used in final position: desoulz I8.8, desquelz 63.7, filz 5.8 , povez 44.7 , serez 65.7 , sottez 50.3 , souliez 17.5 , telz $65.7, v o z$ II.4, 25.6, 52.7. The use of $z$ in phizique 45. . is likely to be due to the fact this term is a Grecism, a learned word.

4) The groups - $c t$ - and - $t t$ - are mostly distributed according to the etymological criterion, eg. doctrine I.3 vs faittes 7.I and passim. It is sometimes difficult to distinguish these two groups in non-etymological contexts, as they are written almost identically; however, it is possible to establish that the dominant spelling is $-t t$-. Thus, I opt for - $t t$ - in doubtful cases, e.g. amourettes 47.2 , flourettes 47.4 .

\section{I.4 Grammar: French text}

The fluctuating usage of the desinence $-s$ of the nominative case (cas sujet) is not regularised, as these fossil remains are present in almost every fifteenth-century French manuscript and represent linguistically valuable information (see, e.g. Marchello-Nizia 1979, 97-IOO).

$$
\text { 3.I. } 5 \text { Editorial interventions }
$$

I) Abbreviations are resolved in italics, e.g. B aquella (title), pendre I4.2; P luxumque I.I, pour I.4.

2) Integrated elements are in brackets, e.g. B bell[s] I4.4; $\mathbf{P}$ seig[n]ourrier 5.6.

3) Expunctions are indicated by angle brackets, e.g. B vostra $\langle s\rangle$ grimaça 37.3; P Cil est $\langle$ est $>$ eureus 2.3.

4) In the French text, round parentheses are used to mark the reconstructed parts of rubrics undoubtedly present in $\mathbf{P}$, but not legible due to the way the book was bound, e.g. $\mathrm{La} \mathrm{m}$ (ort) 5 title, L'empe(reire) 6 title. Reconstructing the word mort involves no difficulty; as for the characters' social rank, I use the form employed in Death's stanza immediately before the stanza of the character in question. As for the rubrics preceding stanzas 65 and 66 , see the respective notes.

$$
\text { 3.I.6 Apparatus }
$$

The critical apparatuses register editorial intervention taking place whenever the manuscripts contain evident errors counter to semantics or syntax and impossible to correct by a sole operation of integration or expunction. The apparatuses are positive: they contain both the emended forms present in the critical text and, separated by a single square bracket, the readings of the respective manuscript, e.g. B 50.8 monstrar] monstrau, P 6.4 un] um. All such corrections are discussed in the editorial notes.

\section{I.7 Numeration}

I) All the stanzas are numbered with Arabic numerals in $\mathbf{B}$, and the same strategy is adopted in the edition. This also applies to the French text, although $\mathbf{P}$ uses no numbers. The numbers differ only for the last four stanzas, since stanzas 64-73 of $\mathbf{B}$ are absent in $\mathbf{P}$. 
2) Folio numbers, enclosed in vertical bars, are indicated in the left margin of each of the two columns containing the respective critical text.

3) Line numeration takes into account the gaps, i.e. the lines lacking in some stanzas. In both editions, such lacunae are indicated by sequences of points. Their position in the stanza is established on the basis of metrical evidence, namely the strophic pattern ABABBCBC; syntactic and semantic structures are taken into consideration as well. In the case of the French text, this kind of evidence is corroborated by the readings of other textual witnesses.

It should be mentioned that the lacunae in $\mathbf{B}$ and $\mathbf{P}$ never coincide and are of a different nature: in the Catalan version, the gaps do not damage the semantic and syntactic integrity of the stanza, whereas the lines lacking in the French manuscript make the text semantically and syntactically incomplete.

\subsection{Critical text}

\author{
Danca de la Mort \\ from MS Miscel-lània 26, \\ Arxiu de la Corona d'Aragó, \\ Barcelona (= B) \\ | Iqor| Dança de la mort e de aquelles persones \\ qui mal llur grat ab aquella ballen e dançen \\ I $\quad$ see B lines I.I-I.7 after stanza 77, \\ which correspond to $\mathbf{P}$ lines I.3-I.6
}

I.

\section{Parle lo Mestre}

O creatura rahonable qui desiges vida terrenal, tu has ací regla notable per ben finir vida mortal. La present dança que veus tal és de la Mort poc delitosa. Morir a tots és natural; la mort és vil, molt odiosa.

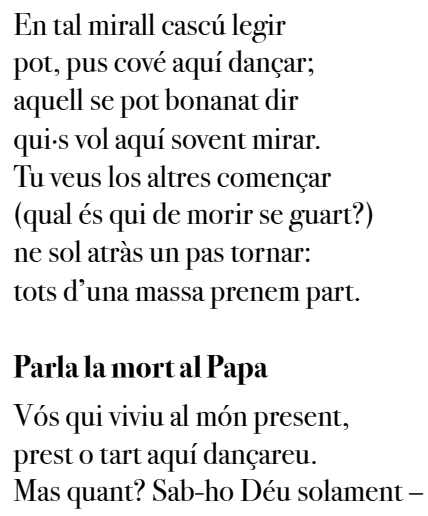

\author{
Dansemacabre \\ from MS lat. 14904, \\ Bibliothèque Nationale de France, \\ Paris (= P)
}

$\left|6_{4} \mathbf{r}\right|$ La dance macabre

Hec pictura decus, pompam luxumque relegat, in que choris nostris ducere festa monet. Discite vos choream, cunctis qui cernitis istam, quantum prosit honor, gaudia, divicie. Tales estis enim matura morte futuri qualis in effigie mortua turba vocat.

O creature raisonnable qui desire vie eternelle, tu as cy doctrine notable pour bien finer vie mortelle. La dance macabre s'appelle que chascun à dancer apprent; à homme et fame est naturelle, mort n'espargne petit ne grant.

En ce miroir chascuns peut lire qui le convient ainsi danser; cil est < est> eureus qui bien se mire: le mort le vif fait avancer. Tu vois les plus grans commencer, car il n'est nul que mort ne fiere; c'est piteuse chose y penser: tout est forgié d'une matere.

\section{Le mort}

Vous qui vives, certainement, quoy qu'il tarde, ainsi danceres. Mais quant? Dieu le scet seulement - 
preneu esment com ho fareu.

Don papa, vós començareu,

axí com pus digne senyor;

en tal forma honrat sereu:

als grans mestres pertany honor.

4.

\section{Respon lo Papa}

Donchs hauré yo menar la dança, qui tinch loch de Déu en la terra? Dignitat haguí e poxança -

e tu, mort, leves-me desferra.

No.m puix lunyar de qui.m fa guerra;

encara morir no cuydava -

yo y pensí poc e fiu gran erra.

5.

\section{A l'Emperador}

Vós qui sou en lo món sens par, príncep e gran Emperador, ara us cové lo món lexar, armes, cavalls e lo pom d'or,

|I/4Ir| sceptre, banderes, gran honor. Forçat sereu venir ab mi, doncs veniu prest, sens fer rumor: tots quants nexen fan tal camí.

6.

\section{Respon lo Emperador}

No trop senyor a qui m’appell de la mort qui axí.m meneja;

la carn, los ossos e la pell

sots un lançol cové que veja.

Tant prest morir yo may no creya què m'ha valgut gran senyoria, pus veig la mort qu·axím garreja? Honor val molt... Si no·s perdia!

7 .
Al Cardenal
Bé·m semble que feu l'esbaït - sus, Cardenal, leugerament, seguiscam tots ab gran delit los altres graciosament! E no us hi valrà l'espantament: haveu viscut ab gran plaer, ab molts delits, honradament - lo gran honor pert lo saber.

\section{8. $\left|\mathrm{I}_{4} \mathrm{IV}\right|$ Respon lo Cardenal}

No.m par sens causa l'espordir, com veig tant prop de mi la mort, e la dança.m cové seguir. En bells vestits no prenc deport: capell vermell, drap de gran sort hauré jaquir e la noblesa.

Bé poré dir hon és ma cort: tot delit fina en tristesa.

9 .

\section{Al Rey}

Veniu, noble Rey coronat, famós de molts béns e proesa, de noble gent acompanyat

advises comment vous feres.

Dam, pappe, vous commenceres, comme le plus digne seigneur; en ce point honnerés seres: aulx grans maistres est dieü l'onneur.

\section{Le pappe}

Hee, fault-il que la dance maine, le premier qui sui Dieu en terre?

$\left|\mathbf{6}_{4} \mathbf{v}\right|$ J'ay eu dignité souveraine

en l'eglise, comme saint Pierre.

Encor point morir ne cuidasse et comme aultres, mort me vient querre, mais la mort à tous maine guerre: peu vault honneur qui si tot passe.

\section{Lam(ort)}

Et vous, le nom pareil du monde, prince et seigneur, grant emperiere, laissier fault la pomme d'or ronde, armes, ceptre, timbre, baniere. Je ne vous lairay pas derriere, vous ne poves plus seig[n]ourrier. J'enmaine tout, c'est ma maniere: les filz Adam fault tous morir.

\section{L'empe(reire)}

Je ne scay devant qui j'appelle de la mort qu'ansi me demaine; armer me fault de pic, de pelle et d'un linseul - ce m'est grant peine. Sur tous ay eu grandeur mondaine, et mourir me fault pour tout gaige et qu'est-ce de mortel demaine? Les grans ne l'ont pas d'avantage.

6.4 un] um

\section{Lem(ort)}

Vous faittes l'esbahi, ce me semble cardinal, sus, legerement

Suivons les aultres tous ensemble: rien n'y vault esbahissement.

Vous aves vescu haultement et en honneurs à grans devis prenes en gré l'esbatement: es grans honneurs se pert l'advis.

\section{Le (cardinal)}

J'ay bien cause de m'esbahir, quant je me vois de si pres pris: la mort m'est venu envair -

$4 \quad\left|6_{5} \mathbf{r}\right|$ plus ne vestiray vair ne gris; chappeau rouge et chappe de pris me fault laissier à grant destresse. Je ne l'avoye pas apris: toute joye fine en tristesse.

\section{Le mort}

Venes, noble roy couronné, renommé de force $e t$ de proesse. Jadis fustes advironné 
e servidors de gran destresa.

Mas de present tota l'altesa

haureu lexar. No sou vós sol,

poch haureu de vostra riquesa:

lo pus rich se·n porta un lançol.

Io.

\section{Respon lo Rey}

Jamés aprenguí de dançar en ball ni dança tan salvatge.

$|\mathbf{I} 4 \mathbf{2 r}|$ Ara pusch veure e pensar què val honor, força, linatge.

Guastar és de la mort usatge, axí del rich com del menor.

Qui-s presa menys ha l'aventatge:

en pols és cascú tornador.

II.

\section{Al Patriarcha}

Patriarcha, per vós bexar

la cara no sou delliurat.

La creu doble renunciar haureu, qu·altre·n serà heretat. No penseu pus en dignitat, no portareu capa de grana. Per donar compte sou citat: folla sperança l'hom engana.

I2.

\section{Respon lo Patriarcha}

Bé conec que moltes honors m'an enganat, per dir lo ver. Mos goigs se giren en tristors, e què val tant honor haver? Pocs són qui no·y prenguen pler, gran stat pert la gent e torbe; massa pujar no-m par sceber: qui munta carregat, s'encorbe.

3. $\left|I_{4} 2 v\right|$ AlCapità o Conestable De mon dret és qu·ab mi vengau molt prestament, bell Conestable: lo pus fort fâs tornar suau, e no us hi qual esser dubtable. No y valrà cara d'espantable ni bravejar ni leig comport: ab tot que no us és agradable, armes no us defendran de mort.

I4.

\section{Respon lo Capità}

Mon parer e intentió

era pendre forces, castells, mettén a ma subjectió

viles, ciutats, locs grans e bell[s].

No·m valen lances ni coltells:

la mort no guarda dret ni leys

ni pobres ni rics ni jovencells -

contra la mort no y ha remeys.

5 .

\section{A l'Archabisbe}

No us qual monstrar la cara fera, mon bell Senyor, acostau-vos.

Haveu vós por que yo no us fera? de grans pompes, de grant noblesse, mais maintenant toute haultesse laiserre $<$ re $>$ s. Vous n'estes pas seul, peu aures de vostre richesse: le plus riche n’a q’un linseul.

Le roy

Je n'ay point aprins à dancer à dance $e t$ note si sauvage.

Helas, on peut vei $<_{0}>$ r et penser que vault orgueil, forse, lingnage. Mort destruit tout - c'est son usage aussi tost le grant que le mendre. Qui moins se prise, plus est sage: à la fin fault devenir cendre.

\section{Le mort}

Patriarche, pour basse chiere vous ne poves estre quitté; vostre double crois qu'aves chiere ung aultre aura, c'est equitté. Ne penses plus à dignité, ja ne seres pappe de Romme, pour rendre compte estes cité: fole esperance decept l'omme.

\section{Le patriarche}

Bien parcoy que mondains honneurs m'ont deceu, pour dire le voir.

Mes joyes tournent en douleurs, et que vault tant d'onneur avoir? Tropt monter hault n'est pas savoir,

$|\mathbf{6 5} \mathbf{v}|$ haulx estas gastent gens sans nombre, mais peu le veullent percevoir: à hault monter le fais encombre.

\section{Le mort}

C'est de mon droit que je vous maine à la dance, gent connestable: les plus fors, comme Charlemaine, mort prent, c'est chose veritable. Rien ne vault chiere espontable ne forte armeure en cest assault; d'un cop j'abas le plus estable: rien n'est d'armes, quant mort assault.

I3.7 un] um

\section{Le con(nestable)}

Je avoie encore entention d'assalir chasteaux et forteresses et mener à subjection, en aquerant honneurs, richiesses. Mais je voy que toutes proesses mort met au bas - c'est grant despit. Tout lui est ung - doulceurs, rudesses:

\section{Le mor(t)}

Que vous tires la teste arriere, arcevesque? Tires-vous pres. Aves-vous paour qu'on ne vous fiere? 
No y dubteu gens, seguiu a nós, e ballem tots de dos en dos.

Anuig ha l'hom qu'a mi s'acoste,

|I43r| lo ball és un poch fastijós:

un jorn cové comptar ab l'hoste.

I6.

\section{Respon l'archabis[b]e}

Trist, no sé veure loch ni part (tant me veig per la mort destret) hon puxa fugir, e m'apart.

Las, hon hauré yo mon retret?

Ara perdré mon benifet, no tendré pus cambra pintada: per la mort, qu·és camí estret, passar cové, cosa·s forçada.

I7.

Al cavaller
Vós qu·entre los altres barons
sou stat noble Cavaller,
oblidau trompes e clarons,
prest veniu, no us mettau derrer.
Las dones solíau voler
e fer dançar ab alegria -
bé podeu veure e sceber:
ço que fa hu, altre u desvia.

18.

\section{Respon lo Cavaller}

Yo dins lo món fuy nomenat

$|\mathbf{I} 43 \mathbf{v}|$ e molt estimat en fets grans, e de nobles dones amat e de senyors richs e poxans, de mercaders e ciutadans, e per null temps fuy variable los comptes meus tots foren vans: jus lo cel no ha res estable.

19.

\section{Al Bisbe}

Prest finirà vostre delit dels béns e de natura, en Bisbe; lo temps és complit, no us valrà vostra prelatura. Vostra fet corra gran ventura: dels súbdits vos cové dar compte. A cascú Déu farà dretura no-s diu segur qui pus alt monte.

20.

\section{Respon lo Bisbe}

Lo cor no.m pot gens alegrar per les novelles que m'apporta. Déu vol tot compte escoltar, e veus ço qui més desconforta. Lo món poc ni molt no $\cdot \mathrm{m}$ conforta ne.n lexa res, ans leva massa. Jamés algú res no s'en porta sinó.l ben fet; tot l'a[lt]re passa.
Ne doubtes, vous venres empres. N'est-pas tousjours la mort empres tout homme et le suit coste à coste? Rendre convient debtes et prest: une fois fault compte à l'oste.

\section{L'arc(evesque)}

Las, je ne scay où regarder, tant suis mort à grant destroit. Où fuiray-je pour moy garder? Certes, qui bien la cong[n]oistroit hors de rason jamais n'istroit. Plus ne gerray en chambre painte:

|66r | mourir me convient, c'est le droit quant faire le fault, c'est contrainte.

\section{Le mort}

Vous qui entre les grans barons aves eu renon, chevalier, oublies tromppettes, clarons et me sieuves, sans sommelier. Les dames souliez resvelier, en faisant danser longue piece aultre dance fault-il veillier: ce que l'un fait, l'aultre despiece.

\section{Le chevalier}

Or ay-je esté auctorisié en pluseurs fais et bien famé, des grans et des petis amé, avec ce des dames amé; ne oncques ne fu diffamé à la court de seigneur notable, mais à ce cop suis tout pasmé: desoulz le ciel n’a riens estable.

\section{Le mort}

Tantost n'aures vaillant ce pic des biens du monde et de nature. Evesque, de vous il est pic, non obstant vostre prelature. Vostre fait git en adventure: de vos subgiés fault rendre compte. À chascuns Dieu fera droiture n’est pas aseur qui trop hault monte.

\section{L'evesque}

Le cuer ne me peut resjoir des nouvelles que mort m'aporte. Dieu vouldra de tout compte oir c'est ce que plus me desconforte. Le monde ausi peu me conforte, qui tous à la fin desherite; il retient tout, nul rien n'emporte: tout se passe, fors le merite.

20.2 vouldra] vauldra 
2I. $\mid I_{44}$ r $\mid$ Algentilhome

Passau avant, en gentilhom, car de dançar sabeu los torns. Moveu-vos prest, no sembleu plom: d'aquest ballar no·n fem tots jorns. Ara fenexen vostres borns; no us membràs may ací venir ne oblidàs delits, sojorns a mort no pot qui viu fugir.

22.

\section{Respon logentilhome}

Pus la mort me té dins son laç, almenys açò $m$ lexarà dir: adéu deports, adéu solaç, ací ja no puix romanir. Vullau vostr-arma favorir, lexau lo cors d'aquí avant. La carn e ossos deu podrir, mas no sab hom hon, com ni quant.

23. Al Abbat

Veniu, Abbat, no fugiau ni façau la cara smortida. Cové la dança seguiscau, ja que l'ajau molt avorrida. Vostra renda ja l'an partida,

$|\mathbf{I} 44 \mathbf{v}|$ qui gras e gros vos ha nodrit; prest vostra carn serà delida: lo pus gros és pus tost podrit.

$24 \cdot$

\section{Respon lo Abbat}

De morir no·m pres may desig, mas só forçat l'estret passar. Poc observí de Déu la lig ne los vots que volguí jurar. Guardau-vos de molt abrassar e pensau que Déu tot ho mira, morir no vullau oblidar: tart és pensar com l’hom expira.

25.
Al Governador
Governador, de molta gent jutge, gran administrador, veniu cuytat, molt prestament, vejam que sereu tornador. Lo poble regís ab furor - d'açò sereu en gran perpleix: en aquell loc sou venidor hon cascú portarà son feix.

26. Respon lo Governador Ay Déu, bé.m par dura jornada, d'aquest colp yo no'm cuydava.

|r45r| La mia roda s'és girada: encara morir no cuydava, en semblants fets jamay pensava, regint ma jurisdictió.

Seria foll qui y contrastava: res no y val n·epellatió. |66v| La mort

Avances-vous, gent escuier, qui saves de dancer les tours. Lance porties et escu hier, et hui vous fineres voz jours.

n'est rien qui ne prengne cours dances et penses de suir. Vous ne poves avoir secours: il n'est qui puisse mort fuir.

\section{L'escuier}

Puis que mort me tient en ses las, aumoins que je puisse ung mot dire: adieu, devis, adieu, soulas,

adieu, dames, plus ne puis rire.

Penses de l'ame qui desire

repos, ne chaille plus tant du corps qui tous les jours empire: tous fault morir, on ne scet quant.

\section{La mo(rt)}

Abbé, venes tost! Vous fuies?

N'ayes ja la chiere esbahie.

Il convient que la mort suyes, combien que moult l'aves haye. Commandes a Dieu l'abbaye que gros et gras vous a nouri $<\mathrm{r}>$; tost porrires à peu d'aye: le premier est premier pourry.

L'ab(bé)

De cecy n'eusse point envie, mais il convient le pas passer. Las, or n'ay-je pas en ma vie gardé mon ordre sans casser! Gardes-vous de trop embrasser, vous qui vives au demourant, se vous voules bien trespasser: on s'advise tart en mourant.

\section{Le (mort)}

Baillif qui saves qu'est justice et hault $e t$ bas, en mainte guise,

$\left|6_{7} \mathbf{r}\right|$ pour gouvrener $<t>$ toute police, venes tantost à ceste assise. Je vous ajourne de main mise pour rendre compte de voz fais au grant juge qui tout ung prise: ung chascuns portera son fais.

\section{Lebailiff}

He, Dieu, vecy dure journée, de ce cop pas ne me gardoye. Or est la chanche bien muée: entre juges honneur avoye, et mort fait ravaler ma joye, qui m’a ajourné sans rappel. Je n’y vois plus ne tour ne voye: contre la mort n'a point d'appel. 
27.
A l'Astròlec
Mestre, per lo vostre mirar
al cel ne per algun sceber
no podeu a morir ascapar,
ne us qual cercar novell carrer.
Hajau açò per cert e ver
e per gran argument e soma:
per Adam, qui fonc lo primer,
moriu per manjar una poma.

28.

\section{Respon l'estròlec}

Per grau algú ni per sciença

no pusch haver provisió.

Ja no.m val res ma sapiença,

ay com és gran confusió!

Eper final conclusió

no scé què·m faça ne m'escriva,

yo pert tota discretió:

qui volrà ben morir, ben viva.

29. $|\mathbf{I} 45 \mathrm{v}|$ AlBurgés

Burgés, cuytau, sens més tardar: no teniu tresor ni riquesa qui us puixa de mort escapar. Si dels béns hon hagués largesa usàs vós bé, fés saviesa.

D’altre vé tot e altre.n gusta, molt ajustar no.m par certesa, car no sap hom per qui s’ajusta.

3 .

\section{Respon lo Burgés}

Gran mal ma fa tant prest lexar

béns temporals e nodridura.

Pobres e rics tu fas lexar,

mort, pus aytal és ta ventura.

No.s prou sabent la creatura

d'amar los béns per què tants ploren

e $t$ acquisits ab prou rancura:

los qui més n’an, pus trists moren.

3I.
Al Canonge
Mossé.l Canonge arrendat,
no pendreu distributions
ne sereu ja pus engrexat
per renda ni oblations.
Pensau en dir orations:
morir haureu. Algú se.n plora?
No y valran appellations:
la mort vé que no guarda l'hora.

\section{2. $\left|I_{4} 6 r\right|$ Respon lo Canonge}

Aquest parlar me fa anuig, què-m val haver tants benifets?

Mon saber ja del tot me fuig.

La mort no guarda leys ne drets,

no.m qual donar, comprar ne pendre almuces ne gentils birrets: en bé morir val més entendre.

\section{Le mort}

Maistre, pour vostre regarder en hault ne pour vostre clergie ne poves la mort retarder: cy ne vault rien astrologie. Toute la genealogie d'Adam, qui fut le premier homme, mort prent, ce dit theologie: tous fault morir pour une pomme.

\section{Le maistre}

Pour science ne pour degré ne puis avoir provision, car maintenant tous mes regres sont mourir à confusion. Pour finable conclusion je ne scay rien que plus descrive, je pers cy toute advision: qui vouldra bien mourir, bien vive.

\section{Le mort}

Bourgois, hastes-vous sans tarder: vous n'aves avoir ne richesse qui vous puisse de mort garder. Se des biens dont e[u]stes largesse

$\left|\mathbf{6}_{7} \mathbf{v}\right|$ aves bien usé, c'est saigesse.

D'aultrui vien tout, à aultruy passe, fol est qui d'amasser se blesse: on ne scet pour qui on amasse.

Lebourg(ois)

Grant mal me fait si tost lessier rentes, maisons, cens, nourreture, mais povres, riches abaissier tu fais, mort, telle est ta nature. Saige n'est pas la creature d'amer trop les biens qui demeurent au monde $e t$ sont siens de droiture: ceulx qui plus ont, plus enuis meurent.

\section{L(e mort)}

Sire chanoyne prebendés, plus n'aures distribution ne gros, ne vous y attendes; prenes cy consolation. Pour toute retribution mourir vous convient sans demeure, ja n'y aures dilation:

\section{Lec(hanoine)}

Cecy gueres ne me conforte: prebendés fus en mainte eglise, or est la mort plus que moy forte, qui tout emmaine, c'est sa guise. Blanc surplis et aumuce grise me faul[t] lesser et à mort rendre que vault gloire si tost bas misse? 
33 .

\author{
Al Mercader \\ Mercader, girau-vos d'açà: \\ cercat haveu del món les vies \\ per mar, per terra, gran temps ha - \\ no us qual fer moltes avaries. \\ Cesseu vostres mercaderies, \\ cuytau lo pas, no sembleu bou \\ ni desigeu trafegueries, \\ que tal cobeja que ha prou.
}

$34 \cdot$

\section{Respon lo Mercader}

Yo só anat amunt, avall, per acquirir béns nit e dia, tot sol, a peu e a cavall, mas ara pert tot.alegria. Ab tot mon poder, com podia, en haver era tot mon seny. Voluntat folla l'om desvia: qui molt abrassa, poc astreny.

35. $\left|I_{4} 6 \mathrm{v}\right|$ AlCartuxà

Veniu, Cartuxà, sens aturar,

e ja no façau resistença: rendes ne camps no us qual may comprar. Pus home sou de penitença, perdonau, hajau paciença: d'aquest món què val la glòria? Veniu ballar prest, sens temença: sobre los vius mort ha victòria.

36.

\section{Respon lo Cartuxà}

Yo só al món gran temps ha mort, e de viure no.m pren enveja, ab tot que $\cdot \mathrm{m}$ sia desconort, quant veig la mort qu·axí.ns bandeja. Placi a Déu l'ànima, veja lo fill de Déu prés mon transpas. Açò m'és cert e yo ben creya: tal hic és vuy, demà no pas.

37 .

$$
\begin{aligned}
& \text { Al porter } \\
& \text { Gentil porter ab la gran maça, } \\
& \text { a mi semble que us rebel·lau. } \\
& \text { No us valrà vostra }<\mathrm{s}>\text { grimaça; } \\
& \text { ab mi veniu, no fugiau. } \\
& \text { Aquesta Dança gens no us plau - } \\
& \text { lo viure va sent que us engana. } \\
& \text { Yo faç lo fort tornar suau: } \\
& \text { lo meu poder los vius aplana. }
\end{aligned}
$$

\section{8. $\left|\mathrm{I}_{47} \mathrm{r}\right|$ Respon lo porter}

Yo só del rey official, e tu, mort, vols me destroir! Bé.m semble joc descominal: yo feya mon offici hir, e veig que, sense més a dir, en dues parts sent que.m tens pres. No pusc scapar ne fugir anujós mor qui no·u ha pres.

\section{Le (mort)}

Marchant, regardes par dessa: pluseur pays aves cerchié à pié, à cheval, depiessa vous n'en seres plus empechié. Vecy vostre desrain marchié:

|68r| il convient que par cy passes. De tout soing seres despeschiés: tel convoite qui a asses.

\section{Le marchant}

J'ay esté amont $e t$ aval pour marchander où je povoye, par long tamps, à piè, à cheval, mais maintenant pers toute joye. De tout mon povoyr acqueroye: or ay-je asses, mort me contraint. Bon fait aler movenne voye: qui trop embrasse, peu estraint.

\section{Le mort}

Ales, marchant, sans plus rester, ne faittes ja cy resistence: vous n'y poves rien conquester. Vous aussi, homme d'astinence, cha[r]treux, prenes en pacience: de plus vivre n'aves memore. Faittes-vous valoir à la dance: sur tout homme [mort] a victoire.

\section{Le chartreus}

Je suis au monde piessa mort, par quoy de vivre ay moins envie, ja soit que tout homme craint mort.

Puis que la char est assouvye,

plaise à Dieu que l'ame ravie soit es cielx apres mon trespas. C'est tout neant qu'est de ceste vie: tel est hui que demain n'est pas.

\section{La mort}

Sergant qui portes celle mace, il semble que vous rebelles. Pour neant faittes la grimace; se on vous griesve, si appelles! Vous estes de mort appellés: qui lui rebelle, il se decoit.

|68v $\mid$ Le plus fors sont tost ravalés: il n'est fort qu'aussi fort ne soit.

\section{Le ser(gant)}

Moy qui sui royal officer, comment m'ose la mort frapper? Je faisoye mon office hier, et elle me vient huy happer. Je ne scey quel part eschapper: je suis prins deca $e t$ dela. Maugré moy me lesse attrapper enuis meurt qui aprins ne l'a. 
39 .
Al Monjo
En Monjo, ab mi dançareu,
e sol no penseu en deffendre.
Pus savi sou, no us aspanteu,
mas ben morir vullau apendre.
E no us qual ja d'uy més contendre,
car tost haureu la boca closa.
Lexau lo donar e lo pendre:
la vida d'hom és poca cosa.

40.

\section{Respon lo Monjo}

Plaguere-m més ésser encara en claustre, fent a Déu servici, alegrement, ab bona cara, matines dir e l'altr.offici. Ara.m conec per foll e nici, perquè volguí seguir l'usança dels mals vivents, comettent vici: may pensí ballar en tal dança.

\section{I. $\left|I_{47} \mathrm{v}\right|$ Al'Usurer}

Usurer, home viciós, veniu ab mi (crec que no us plau)!

D’usurar sou tan cobejós, per guanyar diners tot cremau. Sereu punit, açò cregau; a Déu, qui és omnipotent, qu.ell vos perdó tots jorns pregau: qui mal no fa no sent torment.

42.

\section{Respon lo Usurer}

Doncs axí:m covendrà morir açò m'és anuix e tristesa, e no $\cdot m$ poria subvenir mon or, mon argent e riquesa; mas yo veig la mort tan encesa envers mi que ja.m té dessota:

tal ha bells ulls que no y veu gotta.

$44 \cdot$

\section{Al Metge}

Mirau, metge, vostra orina,

$|\mathbf{I} 48 \mathbf{8}|$ vejau si y fa res esmenar.

Gran mestre sou en medicina

e ben sabent per commendar.

Ara us vé la mort damanar,

e no penseu que viure us leix,

e no y vullau més contrastar:

molt fa qui si mateix goreix.

\section{La m(ort)}

Ha, maistre, par là passeres, n'ayes ja soing de vous deffendre: plus homme n'espoventeres. Apres, moyne, sans plus attendre! Où penses-vous? Ci fault entendre: tantost aures la bouche close. Homme n'est fors que vent et cendre: vie d'omme est moult peu de chose.

\section{Le (moyne)}

J'amasse mieulx encore estre en cloistre $e t$ faire mon service: c'est ung lieu devot $e t$ bel estre.

Or ay-je, comme fol et nice, ou temps passé commis maint vice, de quoy n'ay pas fait penitance souffisant - Dieu me soit propice: chascuns n'est pas joyeux qui dance.

\section{La (mort)}

Usurier de sens desreuglé, venes tost $e t$ me regardes! D’usure estes tant aveuglé que d'argent gaignier tout ardes; mais vous en seres bien lardés, car se Dieu, qui est merveilleux, n'a pitié de vous, tout perdes:

$8 \quad|69 r|$ à tout perdre est cop perilleux.

\section{L'usurier}

Me convient-il si tout mourir?

Ce m'est grant painne et grant grevance, et ne me porroict secourir mon or, mon argent, ma chevance. Je vois morir, la mort m'avance, mais il m'en desplait, somme toute. Qu'est-ce de mal acoustumance? Tel a bieulx yeulx qui ne voit goute.

42.I mourir] mouril

\section{Le povre}

Usure est tant mauvais pechié, comme chascuns dit et raconte; et cest homme qui approchié se sent de la mort n’en tient compte.

Encor à usure me preste.

Il devra de retour au compte:

n'est pas quitte qui doit de reste.

\section{La mort}

Medecin, à tout vostre urine vees vous ycy quamendrer? Jadis sceustes de medicine asses pour povoir commander. Or vous vient la mort demander: comme autres, vous convient morir. Vous n'y povez contremander: 
45 .

\section{Respon lo Metge}

Gran temps ha qu·en malalts gorir -

sab Déu! - mon studi metí.

Per art praticant fiu fugir

la mort d'aquells e departí.

Ara no scé com ne a qui

$m$ 'acost per què. $m$ faça valença:

en morir jamés no pensí;

a la mort no y val resistença.

46.

\begin{abstract}
A l'enamorat
Jove gentil e graciós

qui us estimau de gran valor!

Veniu prop mi, ballem abdos;

lo món lexareu ab dolor.

Argent, vestits ne lo thesor

no us valran aquesta jornada.

Vós no y pensàs e fés follor:

jovent no ha molta durada.
\end{abstract}

47 .

\section{Respon lo enamorat}

O llas, mesquí, socors no trobaré

qui.m puixa de la mort lunyar!

$|\mathbf{I} \mathbf{4} \mathbf{8 v}|$ O trist de mi, per qual camí iré?

Ja no.m calrà més festejar

dones ni ab ellas dançar.

O bé m'engana lo jovent

(pensí devia molt durar):

petita pluja bat gran vent.

48.

\section{A l'Advocat}

Advocat, sens fer gran procès, veniu, no vullau fer contrast!

Les gents per haver molts diners

fés pledejar ab dans e guast,

mas ara mudareu de past

e sereu dins la terra mès.

No manjareu perdius en ast -

açò-s ben cert, vós bé·u sabés.

49 .

\section{Respon lo Advocat}

Bé m’és forçat, més no pusc fer ne sol pensar en fer defença.

Jaquir la mort no tenc voler algú - o trista departença!

Hon és mon saber e sciença?

Bé·s foll qui ab temps no's preveu.

Déu en lo jorn de la venjança

a bons e mals darà just preu.

50.

\section{Al Ministrer}

Ministrer qui dançes e notes, graciós, ab bell continent per alegrar les dones totes,

|I49r| veniu dançar molt prestament! E no us sia gens desplasent dançau, feu bella continença; no us prenga de mi aspavent: mestre monstrar deu de sa sciença.
Le medecin

Longc temps a qu'en l'art de phizique

j'ay mis toute mon estudie,

j'avoye science $e t$ pratique

pour garir maint maladie.

Je ne scey que je contredie;

plus n'y vault herbe ne racine

n'autre remede, quoy qu'on die:

8

contre la mort n'a medicine.

|69v| La m(ort)

Jentil amoureux, jeune $e t$ frique, qui vous cuidies de grant valeur!

Vous estes prins, la mort vous pique;

le monde laires à douleur.

Trop l'aves amé - c'est foleur -

et à mourir peu regardé;

ja tost vous changeres couleur:

beauté n'est qu’image fardé.

\section{L'am(oureux)}

Helas, or n'y a-il secours contre la mort - adieu amourettes!

Moult tost va jonesse à decours -

adieu chappeaus, bouques, flourettes!

Adieu amans et pucellettes,

souviengne-vous de moy souvent

et vous mires, se sages estes:

petite pluye abat grant vent.

\section{Lam(ort)}

Avocat, sans longc proces faire venes vostre cause plaidier!

Bien aves sceu les gens attraire

de piessa, non pas d'uy ne d'ier.

Conseil ne vous peut cy aydier:

au grant juge vous fault venir.

Savoir se deves sans cuidier:

bon fait fait justice prevenir.

\section{L'ad(vocat)}

C'est bien droit que raison se face je n’y scey mettre deffence: contre mort n'a respit ne grace, nul n'appelle de sa sentence.

J'ay eu de l'autruy - quant je y pense de quoy je doubte estre repris.

À craindre est le jour de vengence:

\section{|zor| La mort}

Menestrel qui dances et nottes saves $e t$ aves beau maintien pour faire esjoir sots et sottez, qu'en dittes vous? Alons-nous bien? Monstrer vous fault, puis que vous tien, aux aultres cy ung tour de dance.

Le contredire n'y vault rien:

8 maistre doit monstrer sa science.

5o.8 monstrar] monstrau. 
5.

\section{Respon lo Ministrer}

De tal dançar yo no tenc cura, ans com forçat me n'entremet, car morir és cosa molt dura. Mon estrument vos do e us ret: cançó ne dança ne motet per algun temps no cantaré. Ab tu me'n vaig tot camí dret: tal dança qui al cor no u tè.

52.

\section{Al Curat}

Passau, curat, sens més pensar! Yo sent que us sou als béns donat: morts e vius soliau manjar, mas vós sereu als vèrmens lançat. Vós fós pel Bisbe ordenat al poble per bon exemplari del ben fer sereu gordanat, car tot treball requer salari.

52.7 gordanat] gordattat.

53.

\section{Respon lo Curat}

Forçat só que.m covendrà retre, vençut só yo i pert la batalla.

Haver offertes entremettre

|r49v| no.m qual ne pendre funeralla. O llas! En aquesta gran batalla hauré venir, pus só citat.

L'hom qui no deu diner ne malla és quiti, beneventurat.

$54 \cdot$

\section{Al Cavador}

Pagès qu $\cdot a b$ gran treball e pena tot vostre temps haveu viscut! Forment, molt ordi, mil, avena abundantment haveu hagut. Lo vostre temps és ja vengut morir haureu, no sou desliure, e sereu mès dins un loc brut: foll és qui cuyda tots temps viure.

55.

\section{Respon lo Cavador}

La mort gran temps he desijada, mas volenters li fugiria.

Ma vida trista, trabellada m’à procurat molts mals ab ira. Mon seny e saber se regira, com pens que mon procés és clos en totes parts. Qui bé y remira: dejús lo cell no y ha repòs.

56.

\section{Al frare menor}

Cuytau lo pas, sens més acort,

|I50r| frare menor, e no tardeu.

Vós sovent preicàs la mort,

dient: cascù membrar-se-n deu.

Sens rebel-lar, descalç, a peu,

veniu sens fer altra requesta,

et en açò no contrasteu:

en cascun temps la mort és presta.
Le menestrel

De dancer ainsi n'eusse cure certes, tres enuis je m'en mesle, car de mort n'est peine plus dure. J'ay mis soulxs le banc ma vielle: plus ne corneray sauterelle n'autre dance, mort m'en retient. Il me fault obeir à elle: tel dance à qui au cuer n'en tient.

\section{Le mort}

Passes, curé, sans plus songier! Je sens qu'estes abandonné: le vif, le mort soulies mengier, mais vous seres aux vers donné.

mirouer d'aultrui et examplaire de voz fais seres geurdonné: à toute peine est deu salaire.

\section{Lecuré}

Veulie ou non, il fault que me rende: il n'est homme que mort n'assaille. Hee, de mes parroissiens offrende n'auray james ne funeraille; devant le juge fault que je aille rendre compte - las, douloureux! Or ay grant paor que ne faille: qui Dieu quitte bien est eureux.

\section{Le mort}

Laboureur qui en soing et peine

| $7 \mathbf{0 v |}$ aves vescu tout vostre temps! Mourir vous fault, c'est chose certaine; reculer n'y vault ne contens.

Car de grant soucy vous delivre approchies-vous, je vous attens: fol est qui cuide tousjours vivre.

\section{Lela(boureur)}

La mort ay souhaitié souvent, mais volentier je la fouisse: j'aimasse mieulx - fist pluye ou vent estre en vignes où je fouisse. Encor plus grant plaisir y prisse, car je pers de peur tous propos. Or n'est-il qui de ce pas ysse: au monde n'a point de repos.

\section{La (mort)}

Faites voye, vous aves tort, laboureur. Apres, cordellier! Souvent aves preschié de mort si vous deves moins merveillier. Ja ne s'en fault esmoy baillier: il n'est si fort que mort n'arreste. Si fait bon à mourir veillier: 
57.

\section{Respon lo frare menor}

Què us par del viure d'aquest món ple de tots mals? No y trob repòs: tot quant hic veig, vanitats són. Quan no y pensam, la mort al dòs tenim, qui-ns dóna un tal mos que, sens dir, a la fossa $\cdot n s$ mena. Ay las! E com és enujós morir aquell qui no s'esmena!

$5^{8}$.

\section{A l'Infant}

Petit Infant qu-ara sou nat, al món haureu poc de delit: a la dança sereu manat, lo vostre viure és complit. No y prengau anuig ne despit: axí s'à fer, no y qual més dir. Per Déu és axí conduït: qui més viu, més ha sofferir.

$59 \cdot$

\section{Respon l'Infant}

A, a, a, no sé parlar:

| I5Ov| infan só, tenc la lengua muda.

Hir nasquí, vuy me-n vols menar axí com és trista ma venguda.

Per por suu, ma color se muda; no y fallí $\langle\mathrm{t}\rangle$, per què.m meravell. La voluntat de Déu no·s muda: e mor l'infant, e mor lo vell.

60.
AlScholà
Cuydau de morir ésser luny, clerch aspantat, per recular? Mirau detràs, vejau qui us puny: ja no us qual molt ambarrassar. Molt prest (no cuydeu retardar) bé-n morir metteu vostra pensa, e no us hi qual més contrastar: poc resta d'açò que foll pensa.

6I.

\section{Respon lo Scholà}

Yo, qui tots jorns je trabellat, en fer serveys prenguí plaer; per cuydar ésser avençat morir tant prest yo $\cdot \mathrm{m}$ desesper. Ni gran estat, ni molt haver, ne de gentil sceber lo grau no y val enginy, art ni poder: porta-se·n Déu ço que li plau.

62.

$$
\begin{aligned}
& \text { A l'Hermità } \\
& \text { Veniu ballar vós, hermità! } \\
& \text { Lexau lo bosch, prest levau sus } \\
& \text { sens triga donau-ma la mà: } \\
& \text { estar en l'erm no cuydeu pus. } \\
& \text { Entrar en la fossa dejús } \\
& \text { sereu forçat: aquest viatge } \\
& \text { clergue ni lech no se n'escús - } \\
& \text { vida no·s segur heretatge. }
\end{aligned}
$$$$
\text { | I5Ir| Lexau lo bosch, prest levau sus; }
$$

\section{Lec(ordellier)}

Qu'est-ce que de vivre en ce monde?

Nul homme à sceureté n'y demeure,

toute vanité y abonde,

puis vient la mort qu'à tous cour seure.

Mendicité point ne m'asseure:

des mesfais fault payer l'amende.

En petite heure Dieu labeure -

saige est le pecheur qui s'amende.

\section{La (mort)}

Petit enfant nagueres né, au monde auras peu de plaisance:

| żIr| à la dance seras mené, comme ault[r]es, car mort a puissance sur tous. Du jour de la naissance convient chascuns à mort offrir; fol est qui n'en a congnoissance: qui plus vit, plus a à souffrir.

\section{L'enfant}

A, a, a, je ne scey parler: enfant suis, $j$ 'ay la langue mue. Hier nasquis, hui m'en fault aler je ne fais qu'entreé $e t$ issue.

Rien n'ay mesfait, mais de peur sue; pre[n]dre en gré me fault, c'est le mieulx. Lordonnance Dieu ne se mue: aussi tost meurt jeusne que vieulx.

\section{4 entrée] entrer}

\section{La mort}

Cuides-vous de mort eschapper, cler[c] esperdu, pour reculer? Il ne s'en fault ja deffriper: tel cuide souvent hault aler q'on voit à cop tost ravaler. Prenes en gré, alons ensemble, car rien n'y vault le rebeller:

\section{Leclerc}

Fault-il que jeusne clerc servant, qui en service prent plesir, pour cuidier venir en avant meure si tost? C'est desplaisir. Je suis quitté de plus choisir aultre estat: il fault qu'ansi dance. La mort m'a pris à son plaisir: moult remaint de ce que fol pense.

\section{La mort}

Clerc, point ne fault faire refus de danser - faittes-vous valoir!

|7.'IV| Vous n'estes pas seul - leves sus! pourtant moins vous en doit chaloir. Venes apres, c'est mon vouloir, homme nourry en hermitage! Ja ne vous en convient douloir: vie n'est pas seur heritage. 
63.

\section{Respon lo Ermità}

Algú per molt estar en l'erm no-s excusat que mort no senta. Ara crech que no y ha res ferm, pus a Déu plau, a mi contenta: supplic-lo qu el foc qui tormenta los mals vivents no y sia mès, ne.l vil Satan no·m dón empenta; qui no $\cdot$ s contenta no ha res.

64 .
A la Donzella
Venir ab mi, gentil donzella, haveu; ballar no us sia greu.
Però trossau-vos la gonella que no us embarc, moveu lo peu! Del viure va tost davant Déu haureu donar prestament compte: d'aquest dançar - vós bé u sabeu - no.s excusat rey, duc ne comte.

\section{Respon la Donzella}

Trista de mi, e què faré,

| I5IV| qui no só gens acostumada?

Ni lo compàs ni passos sé, ne.m plau gens la vostra sonada. Yo.m pensí que fos maturada en aquest món pus largament, e tu, mort, veig que m'has citada: albarà tenc d'espatxament.

66.
A la Monge
Lo viure va, molt curiós haveu mudar e la ligaça: Senyora Monge, veniu vós de grat ballar en esta plaça!
A tota gent la mia maça fa tremblar, no y ha remey; a pocs e grans tots jorns dón caça - aquesta.s la mia gran ley.

\section{Respon la Monge}

Jesús beneyt! Què-s ço que dius, o mort cruel, desagradable?

Sens donar temps, tan curt m'escrius ay quant és greu e detestable lexar un loc tan delitable, hon cuydava molt envellir!

|552r| Ara dic qu.és cosa loable qui pensa sovint bé morir.

68.
A la viuda
Madona, vós del front cubert, que viuda sou nomenada! Ballar ab mi crec bé us és cert.
Vós no sou en res occupada, e de dançar acostumada crech no siau molt de temps ha- veniu molt prest pendre posada: tot hom qui viu ab mi venrà.

\section{L'erm(ite)}

Pour vie dure ou solitaire mort ne donne de vivre espace. Chascuns le voit, si s'en faul[t] taire; or requier Dieu q'un don me face: c'est que tous mes pechiés efface. Bien suis contens de tous ses biens desquelz j’ay usé de sa grace: 
69 .

Respon la viuda

No.m pens que $\cdot m$ sia gens honest

ballar a ma conditió,

si.n só forçada; jo y protest,

no.m plau, ne y tenc devotió.

Mes tal és ta intentió,

mort dura, vil, descominal;

no passes de res passió,

per tot loc talla ta destral.

70. A la maridada
Lo jaure calt ab lo marit
vos féu oblidar lo morir -
pensau-hi, no us sia despit.
Lexau los fills, cuytau venir

$|\mathbf{I 5 2 V}|$ en aquest ball, sens contradir, hon ballareu molt gentilmen, e no us vullau enfellonir: tal balle que no.s prou content.

7I. Respon la maridada

Doncs lo marit, fills e parents hauré lexar, los quals tant am.

Ay lassa, greus departiments ab tu ballar! May no·m pres fam.

Bé·m fas de lana bon estam,

o mort cruel e fastijosa!

No sé trobar a qui ma’n clam:

a tot lo món est odiosa.

72. Al notari

Lexau, notari, prest l'escriure

e no cureu més ordenar!

Pensau açí per tots temps viure?

Disponeu-vos ab mi dançar.

Posau apart lo cartajar

e legir libres e contractes;

de morir no us qual appellar:

yo só tal que no serve pactes.

73. Respon lo notari

Bé veig que molta senyoria, mort, tens e gran auctoritat;

| $\mathbf{5 3 3}$ | No.m par que.m faces cortesia, car sens dar temps m'as damanat. $\mathrm{O}$ trist de mi, desconsolat, e què faré, pus axí.m vols? Algun tant visc aconortat, pus al dançar no vaig tot sols.

\section{Conclusió}

Açò $\cdot s$ ben dit, e molt, que.m plau; pus conexeu, sens més scriure, que l'argulós e lo suau per res no-s de mort desliure. Doncs pens-açí molt bé viure, que de bon fet no leu la mà, e porà entre los sancts riure l'hom qui vuy no sab demà.

\section{Le m(ort)}

C'est bien dit, ainsi doit-on dire: il n'est qui soit de mort delivre. Qui mal vit, il aura du pire si pense chascuns de bien vivre. Dieu pesera tout à la livre bon y fait penser soir et main, melieur science n'a en livre: il n'est qui ait point de demain. 
75 .

Aquestes paraules diu un Rey que jau dins una
$\quad$ tomba o moniment
Vosaltres qui la present dança
mirau, ab tota aquesta gent,
avertiu, vejau ma semblança:
yo fuy gran Rey e molt potent;
ara só dins lo moniment,
hon ten podrits tots mos costats -
no seran sabens ni grossers
que no sien als vèrmens lansats.

76.

| 553v | Què d'aquest món (qui y vol pensar)?

Moment e cosa transitòria.

Quescú bé u pot ací mirar,

en lo present ball o història.

Hajau-la sovent en memòria,

car de ben viure us amonesta:

si bé vivim, irem en glòria,

beneyt és qui·n lo cel fa festa.

77. Mas són alguns que may se’n curen ne creen ésser paradís -

estar en infern se procuren,

loc d'orror ple de mal e divís.

Vullau fer molt bé - d'açò us avís -

prest esmenar tots vostres torts:

conseguireu solaç e ris,

lo fer bo val als vius e morts.

I Dicite vos coream

cuncti qui cernitis istam

quantum prosint honor,

gaudia, divitie,

tales estis enim matura morte finiri,

qualis in effigie

matura turba vocat.

Aquesta Dança de la Mort ha compost un sanct home, doctor e canceller de Paris, en lengua francesa, appellat Joannes Climachus sive Climages, a pregàries de alguns devots religioses francesos. Aprés és stada traduïda en lengua catalana. En la fi de la qual ha posat lo dit doctor lo Epigramma qui.s segueix.

\section{II $\left|I_{54} \mathrm{r}\right|$ Epigramma de felicitate et infelicitate hominis}

Mortales Dominus cunctos in luce creavit, ut capiant meritis gaudia summa poli. Felix ille quidem qui mentem jugiter illuc dirigit atque vigil noxia queque cavet. Nec tamen infelix sceleris que $m$ penitet acti quique suu $m$ facinus plangere sepe solet. Sed vivunt homines, tanquam mors nulla sequatur,

\section{Ung roy mort tout nu couchié en(vers)}

Vous qui en ceste pourtraiture vees danser estas divers, penses qu'est humaine nature: ce n'est fors viande à vers. Je le monstre, qui gis envers: si ay-je esté roy couronnés telz serez vous, bons et pervers: tous estas sont aux vers donnés.

66. Ung maistre qui est au bout de la d(anse)

$|7 \mathbf{2 r}|$ Rien n'est d'omme, qui bien y pense: c'est tout vent, chose transitoire. Chascuns le voit par ceste dance, pour ce vous qui vees l'istoire, retenes-la bien en memore, car homme et fame elle admonneste d'avoir de paradis la glore: eureux est qui es cieulx fait feste.

67. Mais aucuns sont à qui n’en chault, comme s'il ne fust paradis n'enfer. Helas, il auront chault! Les livres que firent jadis les sains le monstrent en beaux dis. Acquittes-vous qui cy passes et faittes du bien, plus n'en dis: bien fait vault moult aux trespassés.

$\{\mathbf{P}$ contains this text in lines I. 3 -I.6 at the very beginning of the poem. For the reader's convenience, these lines are repeated below. The original division into lines is maintained, whereas the slashes indicate the end of a line in B:

Discite vos choream / cunctis qui cernitis istam, quantum prosit honor, / gaudia, divicie. Tales estis enim matura morte futuri qualis in effigie / mortua turba vocat\}

\section{Versus magistrales}

Mortales Dominus cunctos in luce creavit, ut capiant meritis gaudia summa poli. Felix ille quidem qui mentem jugiter illuc

4 dirigit atque vigil noxia queque cavet. Nec tamen infelix sceleris quem penitet acti quique suu $m$ facinus plangere sepe solet. Sed vivunt homines, tamquam mors nulla sequatur, 
et velut infernus fabula vana foret. Cum doceat sensus viventes morte resolvi, atque herebi penas pagina sacra probet, quas qui non metuit, infelix prorsus et amens vivit et extinctus sentiet ille rogum. Sic igitur cuncti sapienter vivere certent, ut nichil inferni sit metuenda palus.
8

et velut infernus fabula vana foret.

Cum doceat sensus viventes morte resolvi, atque herebi penas pagina sacra probet, quas qui non metuit, infelix prorsus et amens

I2 vivit et extinctus sentiet ille rogum. Sic igitur cuncti mortales vivere certent, ut nichil inferni sit metuenda palus.

Explicit la Dance Macabre.
II.8 infernus] internus

\section{$3 \cdot 3$ Editorial notes}

\subsection{Catalan text}

[I.2] Terrenal' 'earthly': all the extant witnesses of the French Danse macabre contain eternelle. The substitution of 'eternal' by 'earthly' is likely to be explained on a metrical basis: the Catalan form eterna is paroxytone, which makes it more difficult for a translator to maintain it in the given context without significantly modifying the syntactic structure of the whole stanza. Thus, the translator opts for a phonetically similar but oxytone form, even though this results in the opposite meaning.

[2.I-2.2] As follows from the proposed translation, these two lines can be interpreted in the following way: 'Everyone can read in such a mirror, since we all have to dance here'. Nevertheless, the syntax of this sentence, along with paleographical evidence, suggests a high probability that the form pus ('more' o 'because, since', see DCVB s.v.) is an error for que 'that': the two forms are written very similarly, and a subordinate completive clause introduced by the conjunction que is more preferable than a causative subordinate, considering that an intransitive use of the verb legir 'to read' is rather odd in this context.

[2.5-2.7 This text fragment seems somewhat disconnected. However, if we suppose that line 2.6 is a parenthesis, lines 2.5 . and 2.7 become semantically and syntactically connected.

[2.6] In the manuscript, guart is preceded by part, a word cancelled by Carbonell.

[3.8] B Mestres (capital M).

[4.I-4.7] This stanza contains only seven lines instead of eight, and metrical evidence shows that the lacking line is the final one. As the text of the stanza is semantically and syntactically acceptable and complete, it is impossible to establish if the responsibility for this reduction belongs to the Catalan translator, to the manuscript tradition that produced the French exemplar he used, or to the Catalan manuscript tradition (Carbonell or a copyist of some earlier version).

[6.I] B Senyor (capital S).

[6.6] B Senyoria (capital S).

[6.8] This line was probably produced by an unsuccessful attempt to create a hypothetical period. If so, it would have been: Honor val[dria] molt, si no.s perdia 'Honour would be worth much, if it did not vanish'. However, our translator opts for a syntactically rougher but metrically perfect variant, which we can interpret as 'Honour is worth much... I wish it did not vanish!'

[II.3] Carbonell writes haureu (the first word of the following line) in the end of this line, after renunciar). However, he notices the repetition and cancels the first haureu.

[II.6] Capa de grana 'cape dyed with madder', i.e. a bright red cape.

[12.6] Gran stat: metrical and prosodic evidence makes it likely that this should be read as gran 


\section{[e]stat.}

[I4.2] B Castells (capital C).

[I4.4] B Ciutats (capital C).

[15.2] Senyor 'lord': the structural logic of the French Danse macabre presupposes a precise term denoting the character's social rank at this point. Indeed, a more faithful and precise translation would have been Archabisbe 'Archbishop', like in the rubric preceding the stanza: it is likely that the translator found some metrical difficulty in maintaining Archabisbe in the main text. It is interesting that the word Senyor is written with an initial capital letter, as it indicates that the manuscript tradition - and probably the author himself - is sensitive to the 'rule' of naming each character in Death's stanzas.

[I6.I] At the height of the first line of the Archbishop's stanza, the right margin of the page is annotated with a small pointing hand drawn by Carbonell. The same sign will appear in some other pages containing the Dança de la Mort, namely in stanzas 23 (the Abbot), 29 (Death to the Bourgeois), 30 (the Bourgeois), 42 (the Usurer), 43 (Death against the Usurer), 46 (Death to the Lover), 53 (the Parish Priest), 54 (Death to the Ploughman), 57 (the Franciscan Fryar), 59 (the Child), 62 (the Hermit), 67 (the Nun).

[I7.I] B Barons (capital B).

[I7.2] Sou stat: most probably, this was supposed to be read as sou [e]stat (also v. supra n. I2.6).

[I8.4] B Senyors (capital S).

[18.5] B Ciutadans (capital C).

[I9.2] This line lacks two syllables expected by the metre. We cannot establish with certainty if such metrical irregularity is an error to be attributed to the translator, to Carbonell or to a copyist of some previous version of our poem. However, it is possible that the original Catalan text contained dels bens [del món] e de natura (P has des biens du monde et de nature).

[19.5] Vostra fer: grammatically, the feminine form vostra is not acceptable with a masculine noun fet. It seems plausible that vostra was used instead of vostre as a result of confusion between /a/ and /e/, due to the non-distinction between these two phonemes in atonic positions. This feature is typical of the eastern varieties of Catalan, and it is widely attested in our manuscript: the most demonstrative example is probably the couple $A$ l'Astrolec - l'estrolec in the rubrics preceding stanzas 27 and 28, and other cases of this non-distinction can be found in the same stanza 19: corra for corre 19.5, monte for monta i9.8. Also v. infra n. 27.3.

In addition, in the present context, the confusion seems to have been reinforced by the presence of vostra in the previous line (vostra prelatura I9.4).

[r9.6] B Subdits (capital S).

[20.8] The integration l'a[lt]re is semantically necessary, as the lection lare is not interpretable.

[2I.I] The word gentilhom is a semantic generalisation of a more specific French escuier'a young man who attends a knight before eventually becoming a knight himself’. It is curious that our translator used a more generic word instead of escuder.

[2I.2] B Dançar (capital D).

[24.5] Carbonell marks this line with his usual sign of a hand in the margin (v.supra $\mathrm{n}$. I6.I), this time accompanied by the letters $N O$ surmounted by a tilde.

[27] A l'Astrolec: the rubrics refer to an astrologer, whereas in the main text we find mestre, which perfectly corresponds to the maistre of all the French versions containing this stanza. As for the rubrics, the French manuscript and printed tradition oscillates between le maistre $(\mathbf{P}, \mathrm{MS}$ BnF fr. 25550), l'astrologien (MS BnF fr. I4989, MS BnF fr. ıв86, MS BnF NAF ıоo32, MS Brit. Lib. Add 38858, MS Tours 9O7, MS Saint-Omer I27) or Astrologus (MS BnF fr. IO55) and a lectio singularis le docteur in MS BnF fr. 25434. It is curious that MS BnF fr. II8I contains le maistre astrologien, 
thus putting together the two main variants mentioned above, and Marchant replaces le maistre in his first edition (I485) with l'astrologien in the second (I486). I explain this fluctuating situation with the following conjecture: the Danse macabre mural did not contain any rubrics introducing characters, since they were depicted and, consequently, easily identifiable; as for the manuscripts, most of them contain no images, which caused the addition of the rubrics for greater clarity. ${ }^{34}$ For most characters, the copyists had little doubts when determining which term should be used: they had available such elements as the content of the stanza and the words denoting the social rank in Death's stanzas (v. supra 3.I.I.I); besides, at least some of them could see or have seen the Parisian mural. In the case of the Astrologer's stanza, these different sources of information come into conflict: Death names the character maistre, but the content of the stanza clearly refers to astrology. If my hypothesis is right, the shift between the two lections is to be explained polygenetically and not in genealogical, or stemmatic, terms; and this is probably also the reason why the Catalan translation has l'Astrolec in the rubrics and mestre in the main text.

The oscillation, in the French manuscript and printed tradition, between the readings acteur ('master', 'teacher' or 'authority'), maistre, docteur / Doctor and Macabre (used as a proper name) which takes place in the introductory stanzas, seems to be due to the same reason, i.e. to the passage of the Danse macabre poem from the mural to books, from a hybrid verbal and pictorial form to a prevalently verbal one. 35

[27.3] Ascapar: the first letter is actually an $e$ corrected to an $a$, which illustrates the oscillation between $e$ and $a$ in atonic positions, typical of our manuscript (v. supra n. 19.5).

[29.7] The line is marked in the same manner as line 24.5 .

[30.3] Lexar 'to leave, to abandon': probably a copying error for bexar 'to fall, to go down': $\mathbf{P}$ has abaisser; moreover, the intransitive use of lexar is very odd. This likely substitution is possibly due to the presence of lexar two lines above.

[30.5] The line is marked solely by a drawing of a hand, like line i6.I.

[30.8] Trists is likely to be read as trist/o]s, which makes the line, otherwise lacking a syllable, metrically perfect.

[35.3] The line contains one syllable too many. As our manuscript is the only one extant, it is quite impossible to establish if this hypermetry was generated by the translator himself or by a copying error.

[35.6] The line lacks one syllable. Again, like in line 35.3, we cannot establish if such hypometry is due to a defect of the translation or to a copying error.

[38.I] B Rey Official (capitals R and O).

[38.4] B Offici (capital O).

[38.7] No pusc scapar: metrical and prosodic structure suggests that we should read this phrase as no pusc [e]scapar (also v. supra nn. I2.6, I7.2).

[4I.7] Qu.ell vos perdó: this is a fixed expression where the subjunctive form of the verb perdonar looks like perdó (Déu me perdó, Déu lo perdó, etc.). See DCVB s.v. perdonar.

[42.8] The line is marked by a hand without letters, like line i6.I.

[43] The rubric assigns this stanza to Death, which is interesting, given that the great majority of French manuscripts and printed editions of the Danse macabre agree in attributing it to a poor man or to a borrower.$^{36}$ That indicates that the Parisian mural was also likely to represent a poor

34. This characteristic of the manuscript and printed tradition of the French Danse macabre is briefly discussed in Wijsman 20O5, I4I-I42.

35. For the distribution of these variants between different versions, v. supra 2.2 and fn. 20.

36. A poor man: le povre $\mathbf{P}, \mathrm{BnF}$ fr. 25550 and le povre homme in both Marchant's editions; a borrower: le bon 
man discoursing about the usurer. The only witness that opts for la mort is MS BnF NAF Ioo32. This lectio singularis seems to have the following explanation: for some reason, the rubric preceding this stanza disappeared at some point in the chain of transmission, and the copyist who decided to restore the rubric did not have in mind the mural of the Cemetery of the Innocents - he might have never seen it or he might have forgotten it. The same thing must have happened in the manuscript family that produced the copy to which our Catalan translator had access. I find it unlikely that it was the translator himself who transformed a poor man into Death, as this would be the only case of such a remarkable change in the rubrics.

[43.8] As i6.I.

[45.2] Mon studi: most likely to be pronounced as mon [e]studi (also v. supra nn. I2.6, I7.2, 38.7).

[46] Ne lo thesor: B also contains a cancelled $e$ before $n e$.

[46.8] As i6.I.

[47.I-47.3] Lines 47.I and 47.3 each have two syllables too many. It is possible that the translator, influenced by common formulaic clichés of early Romance lyrical poetry, added mesquí de and de mi. It is also plausible that it was not the translator himself but some copyist in the chain of transmission who added these words - again, under influence of the formulaic style of love poetry.

[49.6] As i6.I.

[50.I-2] In the parallel edition of the French text, the respective lines are the following: Menestrel qui dances et nottes / saves et aves beau maintien 'Minstrel, you who know dances and musical notes and have pleasant manners'. Thus, the forms dances and notes are nouns acting as objects of the verb savoir. As far as the Catalan version is concerned, the forms dançes and notes cannot be nouns, since there is no verb of which they could be the objects. The only plausible interpretation is that the Catalan translator misunderstood the morphological form of dances and nottes in the French poem, i.e. thought they were second person singular verb forms, thus introducing analogous forms in his translation. This is semantically and syntactically acceptable, although it produces some problems of textual cohesion: both in the French and the Catalan poems, Death always uses second person plural forms when addressing her victims. However, I opt for keeping the line unchanged, as any emendation would be unreasonably artificial.

[50.8] I emend monstrau to monstrar on syntactical grounds. The only possible interpretation of this line without any intervention would presuppose an appellative use of the noun mestre: 'Master, show to God his knowledge'. However, it is not acceptable either semantically or syntactically, as it should have been 'your knowledge' and the verb monstrar must take a recipient indirect object, i.e. mostrau [a] Déu. Consequently, the most economical solution is to follow the French text where we read: Maistre doit monstrer sa science. This means replacing the final $-u$ of monstrau with $-r$ : thus, mestre becomes the subject of the sentence, deu becomes the third person singular form of the verb deure, and the meaning of the whole line becomes: 'Master must demonstrate his skills'.

[5I.4] Estrument: Carbonell first wrote estrment and subsequently added a letter $u$ above the line.

[52.7] Gordanat: we can distinctly read gordattat. I emend it, as this lection makes no sense and is paleographically explicable by a confusion between $n$ and $t t$.

[53.2] Vençut só yo i pert: Carbonell first wrote Vençut yo pert and then added so and $i$ above the line.

[53.5] The line has one syllable too many: the initial $O$ was probably added in the chain of transmission.

[53.8] As I6.I.

ho(m)me qui emprunte a usure MS BnF fr. ı186, l'emprunteur MS Saint-Omer ı27, l'omme qui emprunte MSS BnF fr. I4989 and Brit. Lib. Add 38858, ille qui mutuat BnF fr. I055. 
[54.8] As I6.I.

[57.3] Carbonell adds the usual drawing of a hand and a note of his own in the left margin: vanitas va-nitatis et omnia vanitas Ec-cles. (the hyphen marks the passages from one line to another).

[57.3-6] Carbonell marks all these four lines, delimiting them with a vertical line in the right margin and two horizontal lines - above line 57.3 and below line 57.6. He also adds two of the usual drawing of a hand, in the corners formed by the intersection of the three lines; in the upper corner, there are also the letters $N_{o}$ surmounted by a tilde.

[57.8] As i6.I.

[59.6] No y falli<t>: the lection of $\mathbf{B}$ is not syntactically acceptable. Another possible correction could be no $y$ [he] fallit.

[59.7] As i6.I.

[62.8] As I6.I.

[63.5] Elfoc: el is a contraction of $e n+l o$.

[64.5-8] Carbonell marks all these four lines, delimiting them with a vertical line in the left margin. There are also the usual drawing of a hand and a marginal gloss, substantially identical to the one found close to line 57.3: vanitas vani-tatis et omnia vanitas Ecc-les.

[64.5] Delviure va: above the word va Carbonell writes vre surmounted by a tilde, i.e. vostre. It is possible that the copy to which Carbonell had access contained $v a$ surmounted by a tilde, which stayed for vostra (for the desinence - $a$ instead of $-e$, cfr. n. 19.5 above)

[67.7] As i6.I.

[74.2] Més scriure: most likely to be read as més [e]scriure (also v. supra nn. I2.6, I7.2, 38.7, 45.2).

[76.I] As I6.I.

$[76 ; 77$; I] Carbonell writes a note in the right margin, parallel to these three stanzas and occupying equal height in the page: Per ço ara.m ve a la memòria aquella epístola que, stant lo $S$. Rey don Joan, fill del S. Rey don Ferrando primer, en la agonia un dia ans passàs d'esta vida, feu alS. Rey fil seu don Ferrando segon, huy beneventuradament regnant, donant-li a la benedictió paternal, la qual és inserta en la història yo he composta de Hespanya; diu axí, inter alia, in efectu: "Mon fill, pensau que en aquesta agonia haveu a venir; [no] nos facen goig regnes ne conquestes, yo volguera ésser stat lo pus ínfimo vassal de mos Regnes e Senyories, etc." Molt piadosa e profitosa epístola a béviure e foragitar pompas e vanitats de aquest mon és la dita epistola, la qual deuria voler e demanar-lifos tots dies una vegada legida per recordar-se pus sovint que ha morir, car per salut de la ànima no pot ésser millor que cogitar cascun dia que havem a morir. E per açò he scrit açí la dança o ball de la mort. 'So now there comes to my memory the epistle that the Lord King John, son of the Lord King Ferdinand I, wrote in his death throes to his son the Lord King Ferdinand II - who is now happily reigning - giving his son his father's blessing. This letter is inserted in the history of Spain which I wrote; it says, inter alia, in effect: "My son, please think that you will one day be in agony as well; kingdoms or conquests do not make us happy, and now I would like to have been the humblest of the vassals of my kingdoms and estates", etc. This is a very pious epistle, and it can help to live well and reject the pomp and vanity of this world, and we should want to have it read [to us] once a day, in order to remember more often that everyone will die; since, for the soul's salvation, there can be nothing better than to reflect every day on the fact that we will die. And that is why I wrote here the Dance of Death'.

[I.I-I.6] This Latin passage, found in six French manuscripts ( $\mathbf{P}, \mathrm{BnF}$ fr. 2555o, BnF fr. I4989, BnF fr. IO55, BnF NAF IOO32, Lille I39) and both Marchant's editions, features a remarkable concentration of lectiones singulares in the Catalan version - three in seven lines, which actually are not seven but only four, as proven by the metrical form (elegiac distich) and corroborated by the visual arrangement of the text in $\mathbf{P}$ and in the other French witnesses. However, the rather irregular 
division into lines adopted in $\mathbf{B}$ is conserved in the critical text. The lectiones singulares, to be considered as copying errors, are commented on in the notes that follow.

[I.I] Dicite 'tell, recount': an innovation of B. All the extant French manuscripts and printed editions contain discite 'learn'. This is likely to be an interpretation error.

[I.5] Finiri 'be liquidated': an innovation of B, paleographically explicable. The French witnesses of Danse macabre have futuri' going to be, coming, imminent'.

[I.7] Matura 'hastening, having come quickly': an innovation of B, substituting the reading mortua 'as dead people' in $\mathbf{P}$ and in all the other French versions containing this Latin passage. This copying error was most probably generated by attraction, i.e. caused by the presence of the form matura two lines above.

[II.I-I4] This Latin stanza is found in five French manuscripts (P, BnF fr. 2555O, BnF fr. I4989, BnF NAF Ioo32, Lille I39) and in both Marchant's editions.

[II.8] Infernus: B internus is a paleographically explicable error, and it is not plausibly interpretable in the context.

[II.I3] Sapienter: an innovation based on sapientes, the lectio optima found in BnF fr. $14989, \mathrm{BnF}$ NAF Ioo32, Lille I39 and both Marchant's editions. P and BnF fr. 25550, the two manuscripts with provenance from the school of Saint Victor, contain mortales, one of the conjunctive errors which make it possible to postulate a common source for these two copies; at the same time, it forms part of the group of disjunctive errors, which separate these two witnesses from the rest of the manuscript and printed tradition.

\section{$3 \cdot 3 \cdot 2$ French text}

[2.2] Qui le convient ainsi danser: the verb convenir is used transitively, 'who summons them to dance this way'. See $D M F$ s.v. convenir I.A.2.

[6.4] $U n]$ um: this error has a paleographical explanation.

[7.6] À grans devis: modern French à souhait, i.e. 'incredibly, extremely' in similar contexts. See $D M F$ s.v. devis A.3.

[Io.3] Vei<o $>r$ : the form veior is not attested in the $D M F$ database. It is probably a copying error for veoir. See $D M F$ s.v. voir.

[13.7] Un] um: v. supra n. 6.4.

[I7.4] Sieuves: this form is not attested in the $D M F$ database. However, there are attestations of forms with the verb theme siev-, which is very close to sieuv-. It is also possible that sieuves with an added $u$ is a copying error, as it is paleographically explicable.

[r9.I] N'aures vaillant: Middle French avoir vaillant means 'to possess'. See DMF s.v. vaillant II.A.

[20.2] Vouldra] vauldra: an emendation is required, since valoir transitive is not semantically acceptable in this context. Vauldra is a lection of $\mathbf{P}$ and MS Brit. Lib. Add $3805^{8}$, opposed to the majority lection vouldra, found in all the other witnesses containing this stanza.

[35.6] Memore: 'thought' in this context. See DMF s.v. memoire I.5.b.

[40.5] Ou temps passé: ou = en + le. See DMF s.v. ou'.

[42.I] Mourir] mouril: an emendation is necessary, since the reading of $\mathbf{P}$ is an evident copying error.

[48.7] Savoir se: se stands for ce = cela 'this'.

[59.4] Entree] entrer: the emendation is based on the syntax of the phrase, which requires two nouns and not an infinitive and a noun.

[65title] The last letters of the title are hidden because of the way the manuscript was bound. The integration en(vers) is based on the lection of MS BnF fr. $2555^{\circ}$. The title is otherwise identical in 
these two manuscripts.

[66title] $D$ (ance): the same as en(vers) 65 title.

\section{Conclusions and results}

The results of the research into the Catalan translation of the French Danse macabre, presented in this article, have the potential to facilitate future studies on this text and on the Danse macabre tradition in general. The philological study and the critical edition of MS Miscel-lània 26, Arxiu de la Corona d'Aragó, Barcelona provide a basis for further historical, linguistic and hermeneutic research on La dança de la Mort. Moreover, the issues discussed in this paper can have relevance for comparative studies focusing on patterns of transmission and reception of different examples of the Dance of Death genre. Further, the strict dependence of the Catalan text on its French model and its remarkable textual closeness to one of the earliest versions of the Danse macabre (MS BnF lat. I49O4) favour analysis of the Catalan translation as an indirect witness to the lost original text of the French poem. Thus, the results of the present study may be useful not only for an overall study on the transmission and reception of the French Dance, but also for an ecdotic study of this important text, still lacking a critical edition.

\section{English translation}

$\mathrm{T}$ his appendix contains a literal prose translation of the Catalan text into modern English. The variae lectiones of the French text in the version of $\mathbf{P}$ are listed in parallel, according to the structure of negative apparatus (only the divergent variants are included).

In the translation, the pronoun 'she' is used to refer to Death: this choice is based on the fact that Death is a personified character in the poems, and it is feminine in Catalan and in French.

Dança de la Mort

from MS Miscel-lània 26, Arxiu de la Corona d'Aragó, Barcelona (= B)

\author{
Dansemacabre \\ from MS lat. I4904, \\ Bibliothèque Nationale de France, \\ Paris (= P)
}

Dance of Death and of those people who dance with heragainst theirwill

I $\quad\{$ see B lines I.1-I.7 after stanza 7 , which correspond to $\boldsymbol{P}$ lines I.g-I.6
Dance Macabre

This painting banishes pride, vanity and luxury, [and] with this our dance it teaches to lead the celebration.

All you who see it, learn how to dance and what is the real value of honour, joys, riches. Indeed, such will you be in front of hastening Death as the crowd having the appearance of dead people, which summon [you]. 
I. The Authority speaks

O rational creature, you who desire the earthly life, you have a remarkable instruction here on how to end your mortal life properly. This throng of dancers that you see has little taste for Death.

It is natural that everyone dies;

Death is vile [and] most abominable.

2. Everyone can read in such a mirror, since we all have to dance here; we can call lucky the one who is committed to look here often. You can see the others begin [this dance] (who can ever escape from dying?), unable to move a single step back: we participate [in this dance] all together.

\section{Death speaks to the Pope}

You who live in the present world, sooner or later, you will dance here. But when? Only God knows watch carefully how you will do that. Lord Pope, you will begin, as the highest lord; this way you will be honoured: honour is due to those of high office.

\section{The Pope answers}

So must it be me to lead the dance, I who have God's place on Earth? I had dignity and power and you, Death, bring me destruction. I cannot go away from the one who wages war on me; I did not want to die yet I have thought little about it and it was a great mistake.

\section{To the Emperor}

You who have no equal in the world, prince and great Emperor,

now you must leave the world, weapons, horses and the golden orb, sceptre, banners and great honour. You will be forced to come with me, so come quickly, without making noise: whoever is born makes such a journey.

\section{The Emperor answers}

I cannot find a lord I could appeal to against Death who conducts me this way; my flesh, my bones and my skin have I to see under a shroud.

I have never thought I would die so early of what use has been my great majesty, since I can see Death who wages war on me? Honour is worth much... I wish it did not vanish!

8
I title

I.2 eternal life,

I.5-I.8 It is called the Dance Macabre, which everyone learns to dance; it is the natural condition of man and woman, [as] Death spares neither the small nor the great.

2.I in this mirror 2.2-2.8 about who summons them to dance this way; happy is the one who observes himself properly: the dead person makes the living one go forward. You can see those of highest rank begin, as there is no one whom Death does not strike down; it is sorrowful to think about it: [we] all are forged of the same substance.

3 title The Dead

3.I You who live: certainly, 3.2 dance this way.

4 title The Pope

4.I Ah, must it

4.2 the first, I who am God

4.3-4.8 I had supreme honour in the Church, like Saint Peter.

I did not want to die yet and still Death has come to seize me, like others, but Death wages war on us all: of little worth is honour that vanishes so soon.

5 title Death 5.I-5.8 And you [who bear] a comparable title among laymen, prince and lord, great Emperor,

you must leave the round golden orb, weapons, sceptre, plume, banner.

I will not leave you behind, [and] you cannot rule any more.

I carry away everyone, [and] this is my manner: all Adam’s sons must die.

6 title The Emperor

6.I I do not know who I could

6.3-6.8 I have to arm myself with a pick, with a shovel and with a shroud - this is a great grief for me. I have had worldly greatness over all [the others], and I have to die, [and] that is my only payment what does any mortal dominion matter? The great people are not in a favourable position. 


\section{To the Cardinal}

It seems to me that you are perturbed come, Cardinal, let us cheerfully and with great joy graciously

follow all the others!

Being afraid is of no use:

you have had much fun in your life and

many joys, honourably -

great honour loses wisdom.

\section{The Cardinal answers}

It does not seem to me I am scared without reason, as I see Death so close to me,

and I have to follow the dance.

I cannot delight myself with beautiful clothes:

my red hat, my cape of high quality

will I have to abandon and the nobility.

I can tell where my court is:

all joy finishes in sorrow.

9. To the King

Come, noble crowned King,

famous for your many great deeds and for your prowess,

accompanied by nobles

and very adroit servitors.

But now you must abandon

all majesty. You are not alone,

you will get little of your wealth:

the richest man carries away only a shroud.

Io. The King answers

I have never learned to dance

such a savage dance.

Now I can see and reflect on

what honour, power, lineage are worth.

To destroy is Death's custom,

it applies both to the rich and to the most humble.

He who values himself least has an advantage:

each [of us] turns to ashes.

II. To the Patriarch

Patriarch, by lowering your head

you are not saved.

You will have to give up your double cross,

so that another will inherit it.

Do not linger over dignity any more,

[as] you will not wear a cape dyed with madder.

You are called to account for yourself:

foolish hope deceives a human being.

\section{I2. The Patriarch answers}

I know that much honour has deceived me, to tell the truth.

My joy turns to sorrow,

and what use is it to have so much honour?

Those who do not take pleasure in it are very few,

[as] high rank ruins and misleads people;

climbing too high does not seem to me wise:

he who climbs with a load, bends [under the weight].
7 title The Dead

7.3-7.8 Let us follow the others all together:

being afraid is of no use.

You have lived sumptuously

and with incredibly great honour -

enjoy this entertainment:

in great honour wisdom is lost.

8

\section{8 title The Cardinal}

8.I-8.4 I have good reasons to be perturbed, when I see myself held so closely:

Death has come to invade me -

I will not wear vair or grey fur any more;

8.6-8.7 have I to abandon with much distress. I have never learned this:

8

9 title The Dead

9.2 famous for your power

9.3-9.6 You were once surrounded

by great pomp and by great nobles,

but now you will abandon all majesty.

4

$\mathbf{9 . 8}$ possesses only a shroud

8

Io title The King

Io.2 savage dance and music

Io.3 Alas, one can see

Io.4 pride, power

4

Io.5 Death destroys all - it is her custom -

Io.6 both to the great

Io.7 least is a wiser man:

Io.8 in the end, [all] must become ashes.

8

II title The Dead

II.2 you cannot be

II.3-II.4 your double cross that you cherish

will go to another one, this is fair.

Ir.6 [as] you will not become Pope of Rome any more,

8

I2 title The Patriarch

I2.I I am fully aware that wordly honour

I2.5-I2.8 Climbing too high is not wise,

[as] high ranks ruin people without number.

But few are willing to be aware of it:

[their own] actions encumber those who climb high. 
13. To the Captain or Constable

It is my right that you come with me immediately, fair Captain:

I turn meek the most powerful, and there is no need for you to doubt it.

A terrifying appearance will be of no use to you, nor showing off your bravery nor bad demeanour: although this is not pleasant for you, weapons will not defend you from Death.

I4. The Captain answers

My idea and intention

was to take fortresses and castles by assault, bringing under my control towns and cities, great and beautiful places. Lances and daggers are of no use to me: Death does not look at rights or laws or the poor or the rich or the young there is no remedy against Death.

\section{To the Archbishop}

You should not make a ferocious face, my fair Lord, come nearer.

Are you afraid that I will hit you?

Do not doubt it at all; follow us, and let us dance in couples.

Whoever approaches me is in trouble, [as] the dance is a little annoying:

one day [everyone] must account to the host.

\section{I6. The Archbishop answers}

Miserable, I cannot see any place (so closely I see myself pressed by Death) where I could escape, and I stand apart. Alas, where will I have my retreat? Now I will lose my benefice, I will have no painted chamber any more: one must inevitably pass through Death, which is a narrow path.

\section{To the Knight}

You who among the other barons have been a noble Knight, forget trumpets and clarions, come quickly, do not hide in the rear. You used to desire women and make them dance gaily yet you can see and realise [this]: what one makes, another corrupts.

\section{The Knight answers}

I was appointed [to a high-ranking position] in the world

and much appreciated in important affairs, and beloved by noble women and by rich and powerful lords, by merchants and townsmen, and I was not flighty at all all my expectations were vain: there is nothing steady under heaven.
3 title The Dead

I3.I-I3.4 It is my right to bring you

to the dance, noble Captain:

the most powerful, like Charlemagne,

are taken by Death, it is true.

$\mathbf{3 . 5}$ is of no use

I3.6-I3.8 nor strong armour in this assault; with one blow I smash down the firmest person: weapons are nothing when Death attacks.

I4 title The Captain

I4.I-I4.8 I still had an intention

of attacking castles and fortresses and of bringing [them] under my control, acquiring honour and wealth.

But I can see that Death pulls down

all exploits, [and] this is a big disappointment.

Everything is the same for her - gentleness or sharpness:

8 there is no respite against Death.

I5 title The Dead

I5.I-I5.2 Why do you pull your head back, Archbishop? Come nearer.

I5.4-I5.7 Do not doubt it: you will come close.

Is not Death always near

every man, does not she follow him side by side?

It is necessary to return your debts and loans:

8

I6 title The Archbishop

I6.I-I6.8 Alas, I do not know where to look,

as I am killed by the supreme jurisdiction.

Where could I escape to save myself?

Surely, anyone who knew Death well

would never get out of reason.

I will not lie in a painted chamber any more:

I must die, this is the law -

when one must do that, he is bound.

I7 title The Dead

17.I the great barons

17.2 have been renowned, Knight,

$\mathbf{1 7 . 4}$ and follow me, without your pack horse driver.

17.5 to entertain women

I7.6-17.7 making them dance for a long time -

it is time to give attention to another dance:

17.8 another takes apart.

8

\section{I8 title The Knight}

I8.I-I8.7 I was authorised [to participate] in many deeds and I was of good fame, I was beloved by great and small people, and by women, as well;

I have never been dishonoured

in the court of an important nobleman, but with this blow I swoon completely: 
19. To the Bishop

Soon you will cease to enjoy

wealth and gifts of nature,

Bishop; your time is up,

[and] your prelacy will be of no use for you.

Your destiny is in great danger:

you must account for those you are responsible for.

God will judge everyone fairly -

he who climbs higher [than others] cannot be considered safe.

20. The Bishop answers

My heart cannot rejoice at all

from the news that [Death] brings me.

God wants to hear all accounting,

and this is what most makes me uneasy.

I do not take even a little of comfort from this world,

and it leaves us nothing; on the contrary, it takes away

too much.

Nobody ever carries away anything

other than their good deeds; everything else vanishes. 8

2I. To the Squire

Come forward, Squire,

since you know many dance steps.

Move quickly, do not be so leaden:

we do not perform this dance every day.

Now your jousts come to an end;

you have never thought of coming here,

nor have you abandoned enjoyments and pleasant

rest -

he who lives cannot escape from Death.

8

\section{The Squire answers}

Since Death holds me in her net,

at least she will let me say this:

farewell fun, farewell enjoyment,

I cannot stay here any more.

Please favour your soul,

never mind the body henceforth.

Flesh and bones have to rot,

but no one knows where, how and when.

8

\section{To the Abbot}

Come, Abbot, do not flee

or look so mortified.

It is appropriate that you follow the dance,

although you have hated it much.

Others have already divided between themselves your revenue

that fed you and made you bulky and fat;

your flesh will soon vanish:

the fattest is the first to rot.
19 title The Dead

19.I-I9.4 Soon you will no longer have this peak

of worldly and natural wealth.

Bishop, take a pick,

notwithstanding your prelacy.

19.5 is in danger:

I9.8 who climbs too high

2o title The Bishop

2o.I cannot rejoice/

20.2 Death brings

20.3 God will want

20.4 this is what

20.5 I take so little comfort

20.6-20-8 that disinherits everyone in the end;

it keeps everything, nobody carries anything along:

everything vanishes, except one's merits.

2r title Death

2I.I noble Squire,

2I.2 you who know

2I.3-2I.8 You carried a lance and a shield yesterday, and today you will finish your days.

There is nothing that does not float away dance and be careful to follow.

You cannot have help:

there is no one who can escape from Death.

22 title The Squire

22.2-22.8 at least let me say a word:

farewell plans, farewell enjoyment,

farewell ladies, I cannot laugh any more.

Think of the soul that desires

rest, [and] let the body not matter any more,

[the body] that worsens with every day:

everyone has to die, [but] no one knows when.

23 title Death

23.I-23.2 Abbot, come quickly! Do you flee?

Do not look so perturbed.

23.3 follow Death

23.4 hated her

23.5 Commend to God your abbey

23.7-23.8 soon you will rot, without need of much help:

the first [ranked] is the first to rot. 


\section{The Abbot answers}

I have never been taken by the desire to die,

but I have to pass the strait.

I observed very little God's law

or the vows I took of my own will.

Be careful not to embrace too much

and mind that God looks at everything,

[and] do not forget that you will die:

it is too late to think about it when you expire.

25. To the Bailiff

Bailiff, judge of many people,

great governor,

come hastily, very quickly,

let us see you as a debtor.

You governed people with fury -

this puts you in dire straits:

you are about to come to that place

where all will carry their own burden.

26. The Bailiff answers

Oh God, this seems a really hard day to me,

[as] I did not expect this blow.

My wheel [of fortune] has turned:

I did not want to die yet,

[and] I have never thought about similar things,

carrying out my judgement.

It would be foolish to contest it:

even an appeal is useless.

27. To the Astrologer

Master, neither with your gaze

at the heavens nor with any knowledge

can you escape from Death,

nor should you look for a new way.

Be certain of this and consider it true;

consider it a great argument or summation: you die because of Adam, who was the first [human], as a result of his eating an apple.

8

28. The Astrologer answers

No degree or knowledge

can become a source of help for me.

By now my knowledge is of no use to me,

oh, how strong is my confusion!

As a final conclusion

I do not know what to do or what to write,

here I lose any good reason:

if you want to die well, live well.

8

29. To the Bourgeois

Bourgeois, hasten without lingering:

you have neither wealth nor riches

that could save you from Death.

If you made a good use of your ample wealth,

you did so wisely.

Everything comes from others and then others enjoy it; amassing much does not seem safe to me,

since no one knows for whom he amasses [wealth].
24 title The Abbot

24.I-24.4 I had no desire for this at all,

but I have to do the step.

Alas, I did not in my life

keep [fidelity] to my order, without breaking it!

24.6-24.8 during the rest of your lives,

if you want to die well:

it is too late to become wiser when you die.

25 title The Dead

25.I-25.7 Bailiff, you who know what justice is

and high and low, in many forms,

in order to govern all public administration,

come immediately to this court.

I summon you by force

to account for your actions

to the great judge who equally evaluates everyone:

$\mathbf{2 5 . 8}$ all will carry

26 title The Bailiff

26.I this is a hard day,

26.3-26.8 Now my fortune has changed much:

I had honour among judges,

and Death brings down my joy,

[Death] who has summoned me without the option.

I see no solution nor way out any more:

there is no appeal at all against Death.

27 title The Dead

27.2-27.8 upwards nor with your knowledge can you delay Death's coming:

astrology is of no use here.

All the descendants of Adam,

who was the first human,

are taken by Death, this is what theology says:

everyone has to die because of an apple.

28 title The Master

28.I Neither my knowledge nor my degrees

28.3-28.4 since now I completely regret

dying when taken unaware.

28.6 I do not know what to describe,
29 title The Dead

$\mathbf{2 9 . 5}[\ldots]$, this is a wise thing.

29.6 and goes to others.

29.7 Foolish is he who makes sacrifices in order to amass [wealth]:

29.8 no one knows for whom 
30. The Bourgeois answers

It hurts me much to have to abandon so soon

worldly wealth and food.

The poor and the rich you make to leave,

Death, since such is your happiness.

The creature is not wise enough

who cherishes too much wealth for which many people cry,

[wealth] acquired with much trouble:

those who have the most, die the unhappiest.

8

3I. To the Canon

Lord Canon with a revenue,

you will no longer take your contributions, nor will you get fatter

thanks to either your revenue or your oblations.

Focus on saying prayers:

you will have to die. Does anyone cry for this?

No appeal will be useful:

Death comes without looking what time it is.

32. The Canon answers

This discourse troubles me.

What use to me are so many benefices?

My reason now completely abandons me.

Death does not look at laws nor rights,

nor should I give, buy or take [as a gift]

amices or elegant birettas:

it is more useful to endeavour to die well.

\section{To the Merchant}

Merchant, turn here:

you went through the roads of the world

at sea, on land, for a long time -

[now] you do not have to spend much.

Cease your transactions,

speed up your pace, do not look like an ox

or plan any shady deals,

as he who has enough desires [to have more].

34. The Merchant answers

I have been upstream and downstream

to earn wealth, day and night,

alone, on foot and on horseback,

but now I lose all my joy.

With all my efforts, insofar as I could,

my reason was entirely occupied by my possessions.

A foolish desire misleads a human being:

he who embraces much grasps little.

35. To the Carthusian Friar

Come, Carthusian Friar, do not stop,

and do not oppose any more:

you will never more need to gain revenues and fields.

As you are a man of penitence,

forgive [and] be patient:

of what use is the glory of this world?

Come dance quickly, without any fear:

Death has victory over the living.

8

4

8

8 3o title The Bourgeois

30.2-4 my income, houses, capital, food, but the poor and the rich you bring down, Death, such is your nature.

30.5 not the creature

30.6 wealth that remains

3o. 7 in the world, properly belonging to it:

3I title The Dead

3I.I with a prebend

3I.2 have your contributions

3I.3-3r.8 nor wildfowl, nor expect it;

take consolation here.

As your only reward,

you must die without lingering,

you will have no delay:

Death comes when you do not look what time it is.

32 title The Canon

32.I-32.8 I do not take much comfort from this:

I had a prebend in many churches,

[and] now Death is stronger than me,

Death who carries everyone away, this is her manner.

The white surplice and the grey amice

have I to abandon and yield to Death -

of what use is glory so quickly brought down?

8 We must all endeavour to die well.

33 title The Dead

33.r look over here:

33.2 through many countries

33.3-33.7 on foot, on horseback, for a long time -

you will not have this trouble any more.

This is your last transaction:

you have to pass through here.

You will be freed from any concern:

33.8 he who

33 title The Merchant

33.2-33.3 to trade where I could,

for a long time, on foot, on horseback,

33.5-33. 7 all my efforts were directed to earning: now I have enough, Death binds me.

It is good to walk the middle way:

33.8 embraces too much

35 title The Dead

35.I Go, Merchant, do not remain here any more, 35.3-35.8 you can have no profit doing that.

You also, man of abstinence,

Carthusian Friar, take with patience the following:

do not think you will live more.

Show your ability to dance:

[Death] has victory over every human. 
36. The Carthusian Friar answers

I have been dead in the world for a long time, and I am not taken by a desire to live, although I am distressed, when I see Death who ousts us this way. May my soul be pleasing to God, may it see God's son after my passing away. This is certain for me and I firmly believed in it: he who is here today is gone tomorrow.

\section{To the Soldier Sergeant}

Noble Soldier Sergeant with this big mace, it seems to me that you are resisting. Your grimace is of no use for you; come with me [and] do not escape. You do not like this dance at all I feel that a vain life deceives you. I turn meek the most powerful: my power flattens the living.

38. The Soldier Sergeant answers I am an officer of the king, and you, Death, want to destroy me! This seems to me an excessive game: I was doing my duty yesterday, and [today] I see that, without being able to say anything more,

I am gripped by you on both sides.

I cannot escape nor flee -

he who has not learned this, dies troubled.

39. To the Monk

Lord Monk, you will dance with me,

[and] do not even consider defending yourself.

As you are wise, do not fear,

but please learn to die well.

And you no longer need to contend for anything, as soon you will have your mouth sealed.

Leave the idea of giving and taking:

a human life is not much.

8

40. The Monk answers

I would prefer to still be

in the cloister, celebrating mass for God;

gaily, with a serene face,

[I would prefer] to celebrate matins and other services. 4

Now I realise that I am a foolish and stupid man

because I chose to follow the custom

of those who live badly, committing sins:

I have never considered dancing such a dance.

8

4I. To the Usurer

Usurer, sinful man,

come with me (I do not think you like it)!

You are so greedy in your usury

[that] you are all burning [with a desire] to earn money. 4

You will be punished, believe it;

pray Lord, who is almighty,

to forgive you, every day:

he who does no ill feels no pain.

8

8

8
36 title The Carthusian Friar

36.I-36.7 I have been dead in the world for a long time, whereby I have less desire to live, although all men have fear of Death. Since the flesh has come to its end, may it please God that my soul be transported to Heaven after my passing away.

This life is absolutely nothing:

37 title Death

37.I Soldier Sergeant, you who carry this mace,

37.2 it seems that

37.3-37.8 You grimace in vain;

is someone harms you, appea!

You are called by Death:

he who resists her deceives himself.

The strongest ones are quickly brought down:

there is no strong man whose strength cannot be overcome.

38 title The Soldier Sergeant

38.I-38.7 I who am a royal officer,

how dare Death hit me?

I was doing my duty yesterday,

and today she comes to snap me up.

I do not know where to escape:

I am trapped on both sides.

Despite my [resistance], I let her seize me -

39 title Death

39.I-5 Ha, master, you will pass through here,

[and] do not disturb yourself by defending yourself: you will not frighten men any more.

$4 \quad$ You are next, Monk, we should not wait any longer!

What are you thinking of? This is to be understood in the

following way:

39.6 soon you will

39.7 a man is nothing other than wind and ashes:

\section{4o title The Monk}

40.2 celebrating mass:

40.3-40.8 it is a devout place and a good life.

Like a foolish and stupid man,

in the past I committed many sins

for which I have not done enough penitence -

may God be gracious to me:

not everyone who dances is happy.

4 I title Death

4I.I-4I.8 Usurer, having lost any good reason,

come quickly and look at me!

You are so blinded by your usury

that you are all burning with a greed to earn money;

but soon you will be pierced by your avarice,

since if God, who is wondrous,

has no pity on you, you will lose everything:

to lose everything is a dangerous blow. 
42. The Usurer answers

So I must die this way -

this troubles and grieves me,

and my gold, my silver, my riches /42.4/

could not assist me; / 42.3/

but I see Death so inflamed

toward me that she has already put me below her:

he who does not see anything at all has good eyes.

43. Death continues to speak against the Usurer

Usury is an enormous sin,

according to what the law says and tells.

This man is so unsettled

that he does not realise that he has to die.

He himself counts silver with his hand

and lends it to be repaid with interest every day;

counting and counting, he miscounts:

he who has to give rest is not sufficiently free of debt.

44. To the Physician

Physician, look at your urine,

[and] see if it can arrange something here.

You are a great master of medicine

and competent enough to give orders.

Now Death comes to call you,

and do not think she will let you live more,

and please do not object any more:

he who cures himself does much.

8

45. The Physician answers

For so much time I dedicated all my studies -

God knows it! - to healing the sick.

Practising this art, I chased away and eliminated

Death from those people.

Now I do not know how nor to whom

I could go to find encouragement:

I have never thought of dying;

resistance is useless against Death.

46. To the Lover

Noble and gracious Young Man,

you who consider yourself of great merit!

Come close to me, [and] let us dance together;

you will abandon this world in sorrow.

Silver, clothes and wealth

will be of no use to you this day.

You did not think about it, and you did a foolish thing: youth does not last long.

\section{The Lover answers}

Alas, miserable, I will find no help

that could turn me away from Death!

Poor me, what route shall I take?

I can no longer woo women

nor dance with them.

Youth definitely deceives me

(I thought it was to last long):

a small rain brings down a strong wind.
42 title The Usurer

42.I-42.2 Must I die so completely?

This pains and grieves me greatly,

42.4 my silver, my wealth

42.5-42.7 I see myself dying, Death pushes me forward, but I feel sorry for that, all in all.

What is this bad custom?

43 title The Poor Man

43.I-43.7 Usury is so evil a sin,

as anyone says and tells;

and this man who feels

Death approaching him does not realise that.

lends me to be repaid with interest.

He will have to return something, in order to settle his own account:

43.8 is not free

44 title Death

44.I-44.4 Physician, with all your urine

do you see any remedy here?

You once knew enough about medicine

to be able to give orders.

44.6-44.8 Like any other, you must die.

You can countermand this in no way:

he is a good doctor who is able to cure himself.

45 title The Physician

45.I-8 I dedicated all my studies

to the art of medicine, for so much time;

I had knowledge and practical skills

to cure many diseases.

I do not know what to oppose here;

no herb or root is useful any more,

nor any other remedy, whatever could be said:

there is no medicine against Death.

46 title Death

46.I Noble Lover, young and handsome,

46.3 You are captured, [and] Death breaks you through;

46.5-46.8 You loved it too much - this is folly -

and you had scant regard for dying;

soon you will change your colour:

beauty is nothing but a coloured picture.

\section{7 title The Lover}

47.I-47.7 Alas, now there is no help against Death - farewell love affairs!

Youth wanes very quickly -

4 farewell hats, bouquets, little flowers!

Farewell lovers and maidens,

remember me often

and look at yourselves, if you are wise: 


\section{To the Lawyer}

Lawyer, without making a long case,

come [and] please do not oppose!

In order to get much money,

you made people litigate with damage and losses;

but now you will have different food,

and you will be put into the ground.

You will no longer eat partridges on a spit -

this is a certain thing, you know it well.

\section{The Lawyer answers}

I am so forced [that] I can do nothing more nor just think of defending myself.

I have no desire to yield to Death -

what a sad departure!

Where are my skills and my knowledge?

He who does not get ready beforehand is a fool.

God, on the day of vengeance,

will give fair payment to the good and to the bad.

\section{To the Minstrel}

Minstrel, you who dance and write musical notes, gracious [and] able to move elegantly, which is useful to entertain all women, come dance very quickly!

And let it not be unpleasant for you at all -

dance [and] make elegant movements;

do not be taken by fear of me:

the master must demonstrate his skills.

\section{I. The Minstrel answers}

I have no interest in dancing this way; on the contrary, I get involved as I am forced, since Death is a very harsh thing.

I give and cede you my instrument:

a song, a dance or a motet

will I sing never more.

I am going straight way with you:

it is possible to dance even though your heart is not in it.

\section{To the Parish Priest}

Go, Parish Priest, without thinking any more!

I feel that you devoted yourself to your wealth: you used to get your food from the living and the dead, but now you will be thrown to the worms. You were appointed by the bishop as a good example for all people you will be rewarded for your good deeds, as any effort requires a reward.

53. The Parish Priest answers

I am forced, so I must surrender;

I am defeated, and I lose the battle.

I cannot make people give donations, nor can I have a funeral offering.

Alas! To this great battle

I will have to come, as I am claimed.

The one who does not owe money or coins is acquitted [and] blessed.

8

8

8
48 title Death

48.2-48.8 come plead your cause!

You have been able to lure people

for a long time, not just today or yesterday.

No counsel can help you here:

you must go to the great judge.

You must know that without thinking:

A good deed prevents punishment.

49 title The Lawyer

49.I-49.8 It is really right that justice be done-

I cannot defend much here:

there is no reprieve against Death nor pardon from her,

nor does anyone appeal against her sentence.

I obtained much from others - now that I think about it for which I fear to be blamed.

The day of vengeance is to be feared:

God will give everyone a fair payment.

50 title Death

50.I-50.7 Minstrel, you who know dances and musical notes and have pleasant manners,

useful to entertain foolish men and women,

what do you say? Are we doing well?

Since I am gripping you, you have to show

to the others a dance movement.

It is useless for you to oppose:

5I title The Minstrel

5I.I I would have

5I.2-5I.7 surely, I get involved very unwillingly, since there is no harsher punishment than Death.

I have put my fiddle under the bench:

I will never more play a sauterelle, nor any other dance, [as] Death keeps me from that.

I must obey her:

52 title The Dead

52.I without indulging in daydreams!

52.2 I see that you feel abandoned:

$\mathbf{5 2 . 4}$ given to the worms.

$\mathbf{5}^{2.5}$

52.6 mirror and example for others -

$\mathbf{5 2 . 7}$ for your deeds:

$5^{2.8}$ any effort

53 title The Parish Priest

53.I-53.8 Whether I want it or not, I must surrender:

there is no human whom Death does not attack.

Ah, I will never more receive a donation from my parishioners,

nor a funeral offering;

I must go before the judge

to account for myself - alas, sorrowful!

Now I fear greatly that I will fail:

he whom God acquits is happy. 


\section{To the Ploughman}

Peasant, you who in heavy drudgery and hardship have lived all your life!

Grain, much barley, millet, oat

have you had in abundance.

Your time has already come -

you will have to die, [as] you are not free from that, and you will be put in an awful place:

he who thinks he will live forever is a fool.

\section{The Ploughman answers}

I have long wished for Death,

but [now] I would be glad to escape from her.

My sorrowful, hard life

brought me many troubles and much rage.

My mind and reason is deeply upset,

when I think that my case is closed

in every way. If you think it well:

there is no rest under heaven.

56. To the Mendicant Friar

Speed your pace, without thinking it over any more,

Mendicant Friar, and do not linger.

You have often preached about Death,

saying: everyone must remember her.

Without opposing, barefoot, on foot,

come without making any other request,

and do not argue against it:

Death is ready at every moment.

\section{The Mendicant Friar answers}

What does life in this world appear to you,

[as it is] full of evil of every kind? I do not find peace here:

all I can see here is vanity.

When we do not think about it, we have Death upon our back,

[Death] who bites us so that,

without saying much, she brings us to the grave.

Alas! How painful feels

the man who dies without getting better!

\section{To the Child}

Little Child, you who are just born,

you will have little pleasure in this world:

you will be led to the dance,

[as] your life is up.

Do not take it as an annoyance or an offence:

4

it has to be done like that, [and] there is nothing more to say.

God instituted it this way:

he who lives more has to suffer more.

8

8

8
54 title The Dead

54.I in drudgery and hardship

$\mathbf{5 4 \cdot 3 - 5 4 \cdot 7}$ You must die, [and] this is certain;

there is no use in backing away or in arguing.

for she frees you from a great trouble come closer, [as] I'm waiting for you:

55 title The Ploughman

5.5.I often wished

55.3-55. 7 I would prefer - whether in rain or wind to be in the vineyard where I toiled.

$4 \quad$ I would take even greater pleasure there,

for my fear makes me helpless.

There is no one who could exit this place:

$\mathbf{5 5 . 8}$ no rest in this world

56 title Death

56.I-56.2 Move forward, you are wrong,

Ploughman. Next, Mendicant Friar!

56.4-56.7 so you should be less surprised [than others].

You should not be startled at all:

there is no man so strong that he is not stopped by Death.

It is good to be aware of the necessity of dying:

57 title The Mendicant Friar

57.I-57.8 What does it mean to live in this world?

Nobody stays here safely,

[and] it abounds in vanity of different kinds, and after Death comes and cuts everyone down.

A life of poverty is not a guarantee for me:

a fine for misdeeds must be paid.

God works in short time -

wise is the sinner who amends.

$5^{8}$ title Death

58.r Child, just born,

58.4-58.7 like others, as Death has power

over all. From the day of their birth

all must offer themselves to Death;

who is not aware of that is a fool: 


\section{The Child answers}

Ah, ah, ah, I am not able to speak:

I am a child, [and] my tongue is mute.

I was born yesterday, [but] today you want to take me away -

so my arrival is an unhappy thing.

I sweat with fear, [and] I change colour;

I did not sin, [and] that is why I am surprised.

God's behest does not change:

a child dies, and an old man dies as well.

\section{6o. To the Cleric}

Do you think you can be far away from Death, frightened Cleric, by backing away?

Look behind, [and] see who is stinging you: you should not obstruct anything any longer. Immediately (do not think you can delay it) dedicate your thought to dying, and you should not oppose it: very little remains of what a fool thinks.

\section{I. The Cleric answers}

I, who worked every day, took pleasure in serving; for thinking I can be promoted

I die so soon, and I despair.

Neither a high position nor much wealth nor a degree of noble science intelligence, art and power are of any use here: God brings away with him what he finds appropriate.

\section{To the Hermit}

Come dance, you, Hermit!

Leave your forest [and] rise up quickly;

without lingering, give me your hand:

do not think you will live more in the hermitage.

You will be forced to enter the grave below:

this trip does not excuse

either the cleric or the layman -

life is not a secured inheritance.

\section{The Hermit answers}

He who has lived in a hermitage for a long time is not excused from feeling Death.

Now I think that there is nothing steady,

so may it please God he accomplishes my wish:

I beg him not to cast me into the fire

that torments those who lived badly,

nor that evil Satan push me;

he who is not content has nothing.

\section{To the Maiden}

Gentle Maiden, you will have to come with me;

let this dance not be hard for you.

But gather up your skirt

so that it does not disturb you,[and] move your feet.

You will soon have to account

for [your] vain life before God:

this dance - you know it well -

does not excuse a king, a duke or a count.
59 title The Child

$\mathbf{5 9 \cdot 3}$ today I must go away -

59.4-59.6 all I do is enter and exit.

I have done nothing bad, but I sweat with fear;

I must resign myself, [and] this is the best thing.

59.8 the young die as quickly as the old.

8

\section{6o title Death}

6o.r you can escape Death,

6o.2 desperate Cleric

60.3-6o.8 It is useless to twitch about it:

he who often thinks he can go high

is often seen to be suddenly brought down.

Accept it, [and] let us go together,

for it is useless to oppose it:

God punishes everyone who seems appropriate to him.

6r title The Cleric

6I.I Must it be that a young cleric in service,

6r.2 who takes pleasure

6r.3 he can be

6I.4-6r.8 should die so soon? It is an unpleasant thing.

I am banned from choosing

any other position: I must dance this way.

Death has taken me at her pleasure:

much remains [unfulfilled] of what a fool thinks.

\section{2 title Death}

62.I-62.7 Cleric, you must not refuse

to dance - show your ability!

You are not alone - rise up! -

therefore, this must affect you less.

Come along next, [as] this is my will, man who has spent his life in a hermitage!

You should not be upset about it:

63 title The Hermit

63.I-63.7 For [having had] a hard or solitary life,

Death does not give [to whomever] more time to live.

Everyone can see that, and [now] we must keep silent about it; now I ask God to make me one gift:

that is, to efface all my sins.

I am happy with all his good things

I made use of, supported by his grace: 
65. The Maiden answers

Poor me, what will I do,

I who am not used to this at all?

I know neither the rhythm nor the steps,

nor do I like the music you perform.

I thought I would grow up

in this world for more time,

and I see that you, Death, have claimed me:

I have an order to go away.

\section{To the Nun}

You have to change [your] vain life full of cares

and your headwear:

lady Nun, come willingly

dance in this square!

My mace makes all people tremble,

[and] there is no remedy;

I chase the great and the small every day this is my great law.

67. The Nun answers

Blessed Jesus! What is that you are saying,

cruel unpleasant Death?

Without giving me any time, you write to me so briefly-

ah, how hard and detestable it is

to abandon so pleasant a place

where I really intended to grow old!

Now I say that he who often thinks

of dying well deserves praise.

68. To the Widow

Milady, you who wear your head covering,

you who are called Widow!

I think it is certain that you will dance with me.

You are not busy with anything,

and I do not think you have been accustomed to dance

for a long time now -

come very quickly to settle in your new accomodation:

everyone who lives will come with me.

69. The Widow answers

I do not think it is respectable at all

to dance in my situation,

but I am forced; I protest,

[as] I do not like it, nor do I feel devotion toward it.

But such is your intention,

Death, harsh, evil, excessive;

you do not feel compassion for anything,

[and] your hatchet cuts everywhere.

\section{7o. To the Married Woman}

Hot carnal relations with your husband made you forget that you would die -

think about it, do not feel offended.

Leave your children, [and] come quickly

join this dance, without objecting,

[this dance] where you will dance very graciously,

and please do not be angry:

it is possible to dance even though one is not happy

enough. 
7. The Married Woman answers

So I will have to leave my husband, my children and other relatives - those I love so much.

Alas, dancing with you means a hard separation!

I have never suffered hunger,

[but now] you will certainly make a thread of wool for

me,

you cruel and oppressive Death!

I cannot find anyone I could call upon:

[Death] is hateful for everyone.

72. To the Notary

Notary, leave quickly what you are writing and do not think you will give orders any more!

Do you think you will live here forever?

Get ready to dance with me.

Put aside leafing through documents

and reading books and contracts;

you should not appeal against Death:

I am such as does not make pacts.

73. The Notary answers

I really can see that you, Death, have much power and that you are a great authority;

it does not seem to me that you are kind to me,

for you have called me without giving me any time.

Poor wretched me,

what will I do, if you want me this way?

I feel just a little comforted,

as I am not the only one to go dancing.

\section{Conclusion}

This is well said indeed, so I like it;

therefore, be aware, with no more writing,

that the haughty and the meek

are not free from Death at all.

So now be careful to lead a very good life,

so that you do not cease doing good deeds, and he who today does not know his tomorrow will be able to smile among the saints.

75. These words are pronounced by a Dead King who lies in a grave or tomb

You who watch the present dance

with all these people [who participate in it],

pay attention, look at my appearance:

I was once a great king and a very powerful one;

now I am in the grave,

where my body has all rotted -

neither the wise nor the uncouth

will avoid being thrown to the worms.

76. What is this world really, if we reflect on it?

It is just a moment and a transitory thing.

Everyone can well see that here,

in the present dance or painting.

Remember it often,

for it admonishes us about how to live well:

if we live well, we will receive [celestial] glory; those are happy who celebrate in Heaven.
64. 64title The Dead

64.I-64.8 This is well said, thus should one speak:

there is no one free from Death.

He who lives badly will have even worse,

so let everyone think to live well.

God will weigh everything in the scale -

it is good to think about it, in the evening and in the morning, [and] there is no better knowledge in books:

8 there is no one who has no tomorrow.

65. 65 title A Dead King completely naked lying upside down 65.I-65.8 You who, in this painting, see men of different conditions dancing, think about what human nature is: it is no more than food for worms. I, who lie here, demonstrate it, and I was once a crowned king so will you be, the good and the sinners: men of all conditions are given to the worms.

8

66. 66 title A Master speaking at the beginning of this dance 66.I-66.7 A human being is nothing, if we reflect well on it: he is just wind, a transitory thing.

Everyone can see that in this dance; therefore, you who see this painting, save it well in your memory, for it admonishes all men and women to obtain the glory of Heaven: 
77. But there are some people who do not care about it, as if there were no Heaven as a result, they go to Hell, a place of horror, full of evil and dissension. Please do very well - I warn you of that [and] please correct all your errors: you will gain enjoyment and happy laughter, [as] a good deed is of great use for the living and for the dead.

I All you who see it, /I.2/

tell of this dance and of /I.I/

what is the real value of honour,

joys, riches;

indeed, such will you be, when liquidated by Death,

which summons the crowd,

having come quickly.

This Dance of Death was written by a holy man, doctor and chancellor of Paris, in French; his name was Joannes Climacus or Climages, [and he wrote this poem] at the request of some pious religious French people. Subsequently, it was translated into Catalan. In the end of this [poem], the doctor mentioned above put the following Epigram.

II Epigram on human happiness and unhappiness

The Lord created all the mortals in the light, so that they might obtain the supreme joy of Heaven by their merits.

Happy is the one who constantly directs his mind there

and is a watcher aware of everything that is harmful.

Nor is he unhappy who repents of the evil deeds he has done

and often regrets his crimes.

But humans live as if Death were never to come to them,

and as if Hell were only a vain fable.

8

As sense teaches that the living are dissolved by death,

and the holy page proves the punishments of hell,

he who has no fear of them lives as an absolutely foolish man,

and when extinct will feel the funeral pyre.

So, then, let all strive to live wisely,

in order they do not fear the stake of Hell.
67. 67.3-67.7 nor Hell. Alas, they will get hot! The books written by the saints time ago demonstrate this in beautiful stories. Do your duty, you who pass by here, and do good, [and] I will say nothing more on it: 67.8 use for the dead.

I.2 learn how to dance and

I.5 will you be in front of hastening Death, I.7 disguised as dead people
II title Magisterial verses

II.I3 all mortals must fight

\section{Acknowledgements}

am grateful to the editor of Magnificat Rosanna Cantavella (Universitat de València), to Barry Taylor (British Library) and to the anonymous reviewers for their careful reading of my paper, their useful comments and encouragement. I am also grateful to Francesc Massip (Universitat Rovira i Virgili, Tarragona), Artem Serebrennikov (University of Oxford), Igor Mokin (Sechenov Moscow State Medical University), Anna Golikova (Lomonosov Moscow State University), Alexandra Bazhenova (Lomonosov Moscow State University) and Elizaveta Zimont (Leuven Katholieke Universiteit) for their helpful suggestions for improving the content and the form of this article. 


\section{${ }_{7}$ Works Cited}

Aguiló i Fuster, Marià, 1900, Cançoneret de les obretes en nostra llengua materna més divulgades durant los segles XIV, XV $i X V I$, Barcelona, s.e.

Alberni, Anna; Badia, Lola; Cabré, Lluís, ed., 20IO, Translatar i transferir: la transmissió dels textos i el saber (1200-1500), Santa Coloma de Queralt, Obrador Edèndum.

Alcover, Antoni Maria; Moll, Francesc de Borja, I926-I962, Diccionari català-valencià-balear (DCVB), ro vols, Palma de Mallorca, Moll. http://dcvb.iecat.net/

Bofarull, Manuel de, I864-65, Opúsculos inéditos del cronista catalán P.M. Carbonell, Barcelona, vol. 2, 267-96. https://archive.org/details/opsculosinditosoicarbgoog

Calvot, Danièle; Ouy, Gilbert, I99o, L'oeuvre de Gerson à Saint-Victor de Paris: catalogue des manuscrits, Paris, Editions du Centre National de la Recherche Scientifique.

Corvisier, André, I998, Les danses macabres, Paris, Presses Universitaires de France.

Dictionnaire du Moyen Français (DMF), version 20I2, ATILF-CNRS \& Université de Lorraine, http://www.atilf.fr/dmf/.

Eustace, Frances; King, Pamela M., 2OII, "Dances of the living and the dead: a study of Danse macabre imagery within the context of late-medieval dance culture", in Mixed metaphors: the "Danse macabre" in medieval and early modern Europe, Sophie Oosterwijk, Stephanie Knöll ed., Newcastle-upon-Tyne, Cambridge Scholars Publishing, 43-72.

Fein, David, 2013, The Danse macabre:printed by Guyot Marchant, 1485, Tempe, Arizona Center for Medieval and Renaissance Studies.

Freytag, Hartmut, 2OII, "Preface", in Mixed metaphors: the "Danse macabre" in medieval and early modern Europe, Sophie Oosterwijk, Stephanie Knöll ed., Newcastle-upon-Tyne, Cambridge Scholars Publishing, xxi-xxiii.

Gertsman, Elina, 20I0, The Dance of Death in the Middle Ages: image, text, performance, Turnhout, Brepols.

Hammerstein, Reinhold, I980, Tanz und Musik des Todes: die mittelalterlichen Totentänze und ihr Nachleben, Francke Verlag, Bern-Munich.

Harrison, Ann, I994, The Danse macabre of women: ms. fr. 995 of the Bibliothèque nationale, Kent, the Kent State University Press.

Hindley, Alan, 2007, "Un drame macabre? La Mort dans quelques moralités françaises”, European Medieval Drama II, I87-2I2.

Infantes, Víctor, 1997, Las danzas de la muerte: génesis y desarrollo de un género medieval (siglos XIII-XVII), Salamanca, Ediciones Universidad de Salamanca.

Kaiser, Gert, 1983, Der tanzende Tod: mittelalterliche Totentänze, Frankfurt am Main, Insel.

Kovács, Lenke, 20II, "Frightened or fearless: different ways of facing death in the sixteenth-century Majorcan play Representació de la Mort", in Mixed metaphors: the "Danse macabre" in medieval 
and early modern Europe, Sophie Oosterwijk, Stephanie Knöll ed., Newcastle-upon-Tyne, Cambridge Scholars Publishing, 207-36.

Kurtz, Leonard P., 1975, The Dance of Death and the macabre spirit in European literature, Genève, Slatkine reprints (Ist ed. I934).

Marchello-Nizia, Christiane, 1979, Histoire de la langue française aux XIve et Xve siècles, Paris, Bordas.

Marfany, Marta, 20I2, "Balades, lais i rondells francesos en la literatura catalana medieval”, Mot so razo $8, \mathrm{I} 6-26$.

Marfany, Marta, 2OI2, "La influència de la poesia francesa des d'Andreu Febrer a Ausiàs March", Estudis Romànics 32, 259-87.

Massip, Francesc; Kovács, Lenke, 200I, “La Danse macabre dans le Royaume d’Aragon: iconographie et spectacle au Moyen Age et survivances traditionnelles", Revue des Langues Romanes IO5, 2OI-28.

Massip, Francesc; Kovács, Lenke, 2004a, El baile: conjuro ante la muerte: presencia de lo macabro en la danza y la fiesta popular, Ciudad Real, CIOFF-INAEM.

Massip, Francesc; Kovács, Lenke, 2004b, "Les Franciscains et le genre macabre: Les Danses de la Mort et la prédication”, European Medieval Drama 8, 9I-IO5.

Massip, Francesc, 2007, Història del teatre català, vol. I, Tarragona, Arola Editors.

Massip, Francesc; Morrás, María, 2OI4, “El ‘ball de la mort' de Carbonell: una danza macabra cortesana", in Memento mori: il genere macabro in Europa dal Medioevo a oggi. Atti del Convegno internazionale, Torino, 16-18 ottobre 2014, Marco Piccat, Laura Ramello ed., Alessandria, Edizioni dell'Orso, 447-6o.

Massot i Muntaner, Josep, I983, "Notes sobre el text i l'autor de la Representació de la Mort", in Serta philologica F. Lázaro Carreter, Madrid, Cátedra, vol. 2, 347-53.

Merlo, Enrica Z., 2Ooo, "La morte e il disinganno: itinerario iconografico e letterario nella Spagna cristiana", in Humana fragilitas: i temi della morte in Europa tra Duecento e Settecento, Alberto Tenenti ed., Clusone, Ferrari Editrice, 219-50.

Morel-Fatio, Alfred, I872, “Opúsculos inéditos del cronista P.M. Carbonell”, Romania I, 250-4.

Oosterwijk, Sophie, 2004, "Of corpses, constables and kings: the Danse macabre in late-medieval and renaissance culture”, The Journal of the British Archaeological Association I57, 6I-90. http://dx.doi.org/IO.II79/jba.2004.I57.I.6I

Oosterwijk, Sophie, 2008, "Of dead kings, dukes and constables: the historical context of the Danse macabre in late medieval Paris”, The Journal of the British Archaeological Association I6I, I3I-62. http://dx.doi.org/IO.II79/I74767008x330563

Oosterwijk, Sophia, 2009, "Fro Paris to Inglond"? The "danse macabre" in text and image in late-medieval England, Doctoral Thesis, Leiden University. https://openaccess.leidenuniv.nl/ $\underline{\text { handle/1887/13873 }}$

Oosterwijk, Sophie, 20IO, "Death, memory and commemoration: John Lydgate and Macabrees daunce at old St Paul's Cathedral, London”, in Memory and commemoration in medieval 
England (2008 Harlaxton Symposium Proceedings), Caroline M. Barron, Clive Burgess ed., Donington, Shaun Tyas, I85-20I.

Oosterwijk, Sophie, 2OII, "Dance, dialogue and duality: fatal encounters in the medieval Danse macabre", in Mixed metaphors: the "Danse macabre" in medieval and early modern Europe, Sophie Oosterwijk, Stephanie Knöll ed., Newcastle-upon-Tyne, Cambridge Scholars Publishing, 9-42.

Oosterwijk, Sophie; Knöll, Stefanie, ed., 20II, Mixed metaphors: the "Danse macabre" in medieval and early modern Europe, Newcastle-upon-Tyne, Cambridge Scholars Publishing.

Ouy, Gilbert, 1999, Les manuscrits de l'abbaye de Saint-Victor: catalogue établi sur la base du répertoire de Claude de Grandrue (1514), vol. 2, Turnhout, Brepols.

Pearsall, Derek, 1987, "Signs of life in Lydgate's Danse macabre”, in Zeit, Tod und Eigkeit in der Renaissance Literatur, James Hogg ed., Salzburg, Institut für Anglistik und Amerikanistik, Universität Salzburg, 58-7I.

Domínguez Rodríguez, Ana, I993, Iconografía de los Libros de horas del siglo XV de la Biblioteca Nacional, Madrid, Universidad Complutense de Madrid.

Romeu i Figueras, José, 1957-58, "La Representació de la mort, obra dramática del siglo XVI, y la Danza de la Muerte", Boletín de la Real Academia de Buenas Letras de Barcelona 27, I8I-225.

Romeu i Figueras, Josep, 1995, Teatre català antic, vol. 3, Barcelona, Curial.

Taylor, Jane, I989a, “Danse Macabré et bande dessinée: a question of reading”, Forum for Modern Language Studies 25, 356-62. http://dx.doi.org/IO.Iog3/fmls/XXV.4.356

Taylor, Jane, r989b, "Poésie et prédication: la fonction du discours proverbial dans la Danse macabre", Medioevo Romanzo I4, 2I5-26.

Taylor, Jane, I99o, "The dialogues of the Dance of Death and the limits of late-medieval theatre", Fifteenth Century Studies 16, 2 5-32.

Taylor, Jane, 1994, "Translation as reception: La Danse Macabre”, in Shifts and transpositions in medieval narrative, Karen Pratt, Penny Eley ed., Cambridge, D.S. Brewer, I8I-92.

Timofeeva, Olga, 2006, "Word be worde - andgit of andgite: a study of the medieval rhetorical formula", in Selected proceedings of the 2005 Symposium on new approaches in English historical lexis (HEL-LEX), Roderick W. McConchie, Olga Timofeeva, Heli Tissari et al., ed., Somerville, MA, $135-42$.

Warda, Susanne, 20Ira, "Dance, music, and inversion: the reversal of the natural order", in Mixed metaphors: the "Danse macabre" in medieval and early modern Europe, Sophie Oosterwijk, Stephanie Knöll ed., Newcastle-upon-Tyne, Cambridge Scholars Publishing, 73-Ioo.

Warda, Susanne, 20IIb, Memento mori: Bild und Text in Totentänzen des Spätmittelalters und der Frühen Neuzeit, Cologne-Weimar-Vienna, Böhlau Verlag. http://dx.doi.org/Io.7788/ boehlau.97834I22I3695

Warren, Florence, ed., I93I, The Dance of Death edited from mss. Ellesmere 26/A.13 and B. M. Lansdowne 699, collated with the other extant mss, London, Oxford University Press.

Whyte, Florence, I93I, The Dance of Death in Spain and Catalonia, Baltimore, Waverly Press. 
Wijsman, Hanno, 2005, "La Danse macabre du cimetière des Saints-Innocents et un manuscrit de Philippe le Bon", in Douzième congrès international d'études sur les Danses macabres et l'art macabre en général (Gand (Gent), Belgique, 21-24 Septembre 2005), Meslay-le-Grenet, Association Danses Macabres d'Europe, vol. I, I35-44.

Zvonareva, Alina, 20I3, “Traduire la Danse macabre: la réception du modèle français dans les terres du Royaume d'Aragon”, in Alessandra Petrina ed., The Medieval Translator: Traduire au Moyen Age 15, "In principio fuit interpres", Turnhout, Brepols, 29I-3O2. 